ISSN: 0213-2060

DOI: http://dx.doi.org/10.14201/shhme201634149185

\title{
RELACIONES ENTRE NOBLEZA Y MONARQUÍA EN EL SIGLO XV: FACCIONALISMO Y ACCIÓN POLÍTICA DE LOS ÁLVAREZ DE TOLEDO (CASA DE ALBA)
}

\author{
Relationships between Nobility and Monarchy in the Fifteenth Century Castile: \\ Factionalism and Political Action of the Alvarez de Toledo (Casa de Alba) \\ José María MONSALVO ANTÓN \\ Depto. de Historia Medieval, Moderna y Contemporánea. Facultad de Geografia e Historia. Universidad de \\ Salamanca.C/Cervantes, s/n.E-37002 SALAMANCA. C. e.: monsalvo@usal.es
}

Recibido: 2016-03-30

Revisado: 2016-10-24

Aceptado: 2016-10-24

RESUMEN: La formación de patrimonios señoriales, la obtención de títulos nobiliarios y el disfrute de transferencias fiscales dependía, para la alta aristocracia castellana, de las concesiones de los reyes. Entre otros recursos, para favorecer estas concesiones, los nobles recurrieron a la formación de facciones. Con sus alianzas y pactos generaban conflictos en el reino y acababan siendo recompensados por los monarcas. Se comprueba en este caso en el linaje de los Álvarez de Toledo, Casa de Alba, a lo largo del siglo xv. Se quiere mostrar en el trabajo la estrecha correspondencia entre historia política, faccionalismo y engrandecimiento del linaje.

Palabras clave: Condes de Alba; Faccionalismo; Ligas nobiliarias; Castilla; Siglo Xv.

ABSTRACT: For high aristocracy of Castile, the lordships, titles of nobility and many incomes were granted by kings. Among other resources, to promote these concessions, the nobles used factionalism. With its alliances and pacts generate conflicts in the kingdom and ended up being rewarded by monarchs. It is checked in this case about the lineage of the 
JOSÉ MARÍA MONSALVO ANTÓN

RELACIONES ENTRE NOBLEZA Y MONARQUÍA EN EL SIGLO XV: FACCIONALISMO Y ACCIÓN POLÍTICA DE LOS ÁLVAREZ DE TOLEDO (CASA DE ALBA)

Alvarez de Toledo, House of Alba, along the $15^{\text {th }}$ Century. This paper wants to show the correspondence between political history, factionalism and ascent of the lineage.

Keywords: Counts of Alba; Factionalism; Noble leagues; Castile; $15^{\text {th }}$ Century.

SUMARIO: 0 Introducción. 1 Encumbramiento del linaje a través del faccionalismo. 2 Diversidad y condiciones de las alianzas y pactos. 3 Conclusión. 4 Anexo. Los Álvarez de Toledo y las parcialidades, 1430-1479. 5 Referencias bibliográficas.

\section{INTRODUCCIÓN}

Los Álvarez de Toledo-Casa de Alba eran ya en 1488, cuando don Fadrique heredaba el gran estado señorial, uno de los principales linajes nobiliarios castellanos ${ }^{1}$. Bajo la tutela de su tío don Gutierre, señor de Alba en 1430, Fernando Álvarez de Toledo († 1464), primer conde de Alba, y luego su hijo García († 1488), primer duque, fueron los grandes artífices. Desde 1369 la familia disponía del señorío de Valdecorneja. Pero el gran salto se produjo ya en época de Juan II. Nos interesa comprobar el influjo del faccionalismo ${ }^{2}$ en el encumbramiento del linaje. Hace ańos pude entrar en contacto con el tema en la tesis doctoral. Con posterioridad se fue publicando la documentación utilizada entonces y otra nueva. Es conveniente plantear si esta documentación, así como los nuevos estudios y monografías ${ }^{3}$, permiten completar la información disponible y encuadrar lo observado en

1 En esa época estaba ya forjada la veintena de linajes que a principios del siglo xvi nutrieron expresamente la grandeza, pero que desde el siglo xv venían protagonizado un proceso de «engrandecimiento». Vid. Quintanilla Raso, María Concepción. «El engrandecimiento nobiliario en la Corona de Castilla. Las claves del proceso a finales de la Edad Media». En Quintanilla Raso, María Concepción (ed.). Títulos, grandes del reino y grandeza en la sociedad política: sus fundamentos en la Castilla medieval. Madrid: Sílex, 2006, pp. 17-100, entre otros muchos trabajos de la autora.

2 Hoy por hoy, la palabra no figura en el Diccionario de la RAE. Hay autores que emplean «faccionarismo», tan aceptable como "faccionalismo», que utilizamos aquí. Este último se acerca más a la voz inglesa factionalism, de amplio uso, cuyo significado puede ser coincidente con lo que se quiere expresar aquí.

3 Luis López, Santos Canalejo y yo mismo abordamos en los años ochenta en nuestras tesis doctorales la señorialización de Piedrahíta, El Barco o Alba de Tormes y nos topamos ya con la Casa de Alba. En la década siguiente este linaje y los estados señoriales fueron objeto de la tesis de J. M. Calderón Ortega. Vid., entre otros, Luis López, Carmelo. La Comunidad de villa y tierra de Piedrahita en el tránsito de la Edad Media a la Moderna. Ávila: Institución Gran Duque de Alba, 1987; Í́Dem. "El seńorío de Valdecorneja». En SER QuiJANo, Gregorio del (coord.). Historia de Ávila. Tomo III. La Edad Media (Siglos XIV y XV). Ávila: Institución Gran Duque de Alba, 2006, pp. 279-370; Santos Canalejo, Elisa Carolina de. La historia medieval de Plasencia y su entorno geohistórico: la sierra de Béjar y la sierra de Gredos. Cáceres: Institución Cultural El Brocense, 1986; Monsalvo Antón, José María. El sistema político concejil. El ejemplo del señorío medieval de Alba de Tormes y su concejo de villa y tierra. Salamanca: Ediciones Universidad de Salamanca, 1988; ÍDEM. "Arraigo territorial de las grandes casas señoriales (infantes de Aragón, Alba, Estúñiga y Alburquerque) en la cuenca suroccidental del Duero en el contexto de la pugna "nobleza-monarquía" ". Anales de la Universidad de Alicante. Historia Medieval, 2015-2016, vol. 19, pp. 111-164; CALDERÓN ORTEGA, José Manuel. «Aspectos políticos del proceso de formación de un estado señorial: el ducado de Alba y el señorío de Valdecorneja (1350-1488)». Cuadernos Abulenses, 1995, vol. 23, pp. 11-116; ÍDEM. «Los riesgos de la política en el siglo xv: la prisión del conde de Alba (1448-1454)». Historia. Instituciones. Documentos, 1994, vol. 21, pp. 41-62; Ídem. El ducado de Alba. 
JOSÉ MARÍA MONSALVO ANTÓN

RELACIONES ENTRE NOBLEZA Y MONARQUÍA EN EL SIGLO XV: FACCIONALISMO Y ACCIÓN POLÍTICA DE LOS ÁLVAREZ DE TOLEDO (CASA DE ALBA)

tendencias generales de la Castilla del siglo Xv, hoy mejor conocidas que entonces dados los avances empíricos y de interpretación.

Se puede reconstruir con bastante detalle la implicación de los Álvarez de Toledo en las luchas políticas de su tiempo. La correlación entre las coyunturas generales de Castilla, los propios avatares de la familia y el resultado de lo obtenido -en títulos y señoríos-, que se refleja en el cuadro ${ }^{4}$, no es solo una forma de ordenar la información, sino una hipótesis sobre el faccionalismo como recurso político. El cuadro revela la estrecha correspondencia entre historia política, alianzas y patrimonio señorial del linaje.

\section{ENCUMBRAMIENTO DEL LINAJE A TRAVÉS DEL FACCIONALISMO}

Aparte del marco estructural -a mi juicio, la monarquía centralizada-, en el auge del linaje, desde el punto de vista de las decisiones y factores personales, influyeron varios: la propia familia, es decir, ese origen que situaba ya a sus miembros en una posición determinada ${ }^{5}$; ciertas aptitudes y méritos individuales, de los que en este caso concreto habría que destacar la carrera militar en los ańos veinte y treinta del siglo xv de Fernando Álvarez de Toledo ${ }^{6}$; los matrimonios de los miembros de la Casa, en este caso fundamentalmente el de Fernando Álvarez de Toledo con Mencía Carrillo y el de su hijo García con María Enríquez -hija de don Fadrique-; finalmente, las alianzas.

Aunque todo influía en todo ${ }^{7}$, aquí no incidiré en la cuestión del origen, ni en la carrera militar ni en la política matrimonial, sino en la cuestión de las alianzas y facciones.

La evolución histórica, el gobierno y la hacienda de un estado señorial (siglos XIV-XVI). Madrid: Dykinson, 2005; ÍDEM. «El gobierno de la Casa de Alba (siglos XIV-Xvi)». En Ser QuiJano, Gregorio del (coord.). Congreso V Centenario del nacimiento del III Duque de Alba Fernando Álvarez de Toledo. Actas. Ávila: Institución Gran Duque de Alba, 2008, pp.119-153. En cuanto a la documentación, gracias a varias publicaciones -en especial de Calderón Ortega, Á. Vaca y J. A. Bonilla- se ha podido incrementar en las últimas décadas. Vid. el Anexo del cuadro de acontecimientos, en cuya nota inicial se hallan las referencias documentales. En el caso de José Manuel Calderón Ortega no solo ha publicado documentación del ducado de Alba, en especial la referida a Ávila, sino también la importante documentación de don Álvaro de Luna, personaje central en la época. También remito a ese cuadro para las referencias abreviadas de las crónicas utilizadas en estas páginas.

4 Cfr. Anexo, con el cuadro de acontecimientos.

5 Se incluye aquí una escueta genealogía. Las circunstancias y acciones individuales gestionaban una herencia de prestigio y abolengo. En el caso concreto de la familia, aparte de los dos individuos que aquí nos interesan, Fernando y su hijo García, el tío del primero, don Gutierre, primer señor de Alba de la Casa, obispo y cortesano, desempeñó un papel importante en ciertos momentos del reinado de Juan II. Vid. NiETo SoriA, José Manuel. Un crimen en la Corte. Caida y ascenso de Gutierre Álvarez de Toledo, señor de Alba (1376-1446). Madrid: Sílex, 2006.

6 Fue Capitán Mayor de la Frontera, donde luchó muy activamente en 1430-1431, Crónica de Juan II, García de Santa María, t. C, pp. 221, 243-244, 272 y 283. En las campañas de Ronda la crónica destaca el valor y eficacia de Fernando Álvarez de Toledo: «los moros curaban más de guardar sus lugares que de salir a pelear con él», Crónica de Juan II, p. 244. Destacó también militarmente entre 1433 y1436, Crónicas BAE II. Juan II, II, pp. 487-499, 512, 520, 523 y 527-528, entre otras.

7 Vid. las monografías citadas en nota 3, en especial Calderón Ortega, El ducado de Alba. Interesa señalar que estos factores estaban relacionados con las alianzas. Por ejemplo, los matrimonios de los Alba que enlazaban con Carrillo y con Fadrique Enríquez influyeron en sus acercamientos correspondientes, respectivamente, a Álvaro de Luna o al almirante Enríquez, cuya hija María era hermana de la esposa del infante 
JOSÉ MARÍA MONSALVO ANTÓN

RELACIONES ENTRE NOBLEZA Y MONARQUÍA EN EL SIGLO XV: FACCIONALISMO Y ACCIÓN POLÍTICA DE LOS ÁLVAREZ DE TOLEDO (CASA DE ALBA)

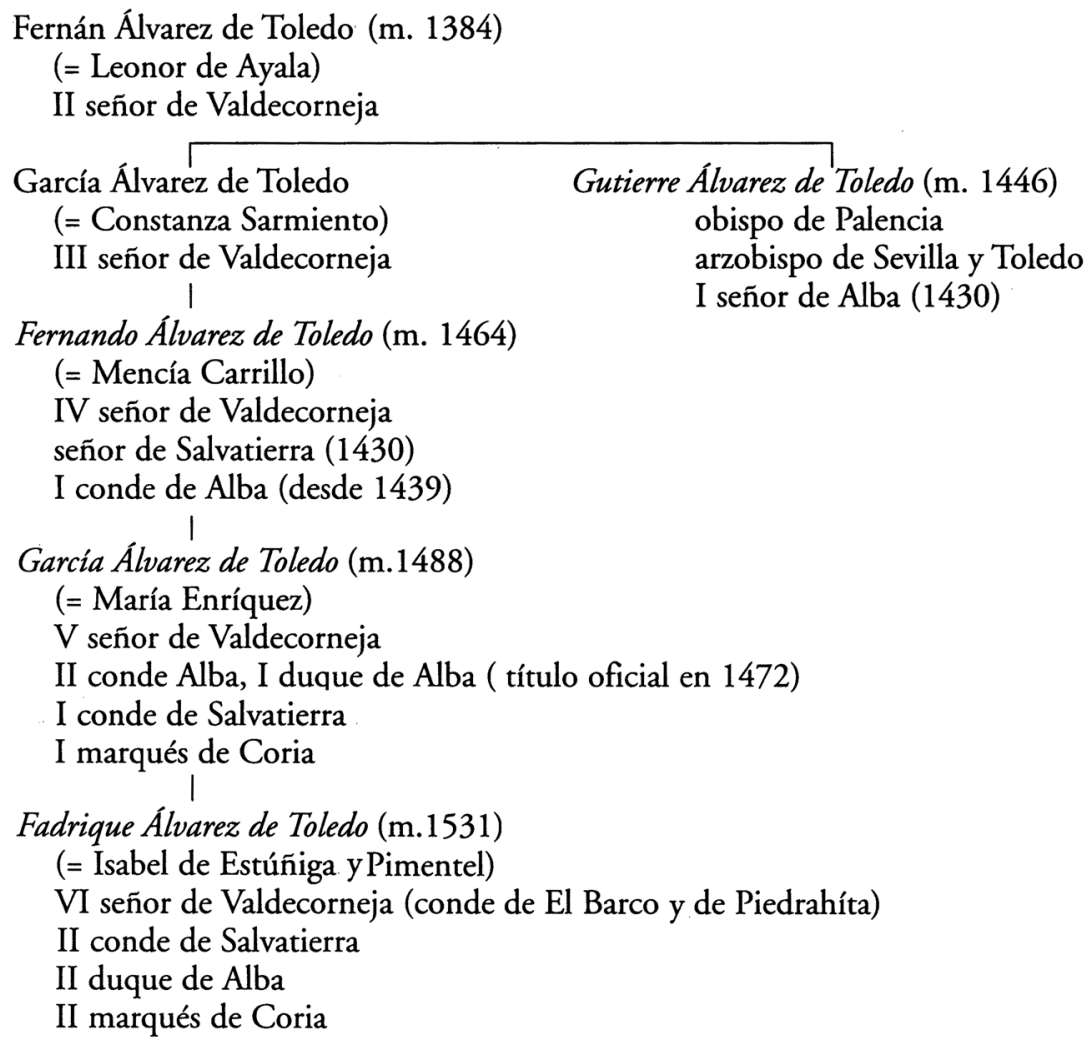

Sin duda, hubo momentos decisivos para el destino de los Alvarez de Toledo ${ }^{8}$. En el reinado de Juan II, uno de estos momentos fue la alianza con Álvaro de Luna antes de 1430, que aportó Alba y Salvatierra y situó al linaje en primera línea. Después, la unión que mantenía con Luna en 1439 venía obligada, ya que si ganaban los infantes reclamarían Alba y otros señoríos que perdieron en 1430, así como las mercedes de las que se les había privado en 1438 y que en parte disfrutaba el de Alba transferidas por su suegro. La cercanía a Luna le valió participar en las negociaciones de 1439-1441, que dejaron a Fernando Álvarez de Toledo muy bien posicionado cuando se produjo la victoria del condestable en Olmedo en 1445, magníficamente recompensada con títulos,

Juan de Aragón. Y por lo que respecta a los méritos militares, obviamente eran también tenidos en cuenta en el ascenso del linaje. Por ejemplo, en 1444 el príncipe don Enrique, de acuerdo con Juan II, al conceder el alguacilazgo mayor de Ávila, que le había sido otorgado pero que no había podido ser efectivo, decía hacerlo, entre otras razones, por los «serviçios que vos a su merçed [a Juan II] fezistes en la guerra de los moros", DCasaAlba-Ávila, doc. 19.

8 Monsalvo Antón, El sistema político concejil, pp. 40-62; Calderón OrTega, El ducado de Alba; ÍDEM, «Aspectos políticos del proceso de formación»; ÍDEM, «Los riesgos de la política en el siglo XV». 
JOSÉ MARÍA MONSALVO ANTÓN

RELACIONES ENTRE NOBLEZA Y MONARQUÍA EN EL SIGLO XV: FACCIONALISMO Y ACCIÓN POLÍTICA DE LOS ÁLVAREZ DE TOLEDO (CASA DE ALBA)

rentas y señoríos en el norte de la actual Extremadura. Después el auge del príncipe don Enrique alteró los equilibrios. Un momento difícil derivó de la alianza hacia 1447 del conde de Alba con el almirante Fadrique -obligada por el matrimonio de don García con su hija- y que acarreó, indirectamente, un acercamiento a los infantes. Pero esto supuso enfrentamiento con el príncipe, alejamiento de la corte e incluso prisión de Fernando Álvarez de Toledo entre 1448-1454. Encarcelado por Luna y enemistado con el príncipe, en su resistencia -la de García para liberar a su padre- se acabó alineando con aquellos que hicieron posible la caída del Condestable, lo que le hizo ganar posiciones, máxime cuando el príncipe empezó a liderar la oposición a Luna. Solo el interés directo del príncipe Enrique por las villas confiscadas en 1448 retrasó la salida de prisión, que se demoró hasta 1454. Entonces recuperó su posición en la corte.

Después se acercó al rey Enrique IV y a Juan Pacheco desde 1454. Hizo movimientos vacilantes entre 1457-1461, llegando a cambiar de bando, para retomar luego la sintonía con Enrique IV. Tras otro cambio en 1464, el alineamiento del nuevo titular de la Casa, don García, con el monarca entre 1465-1467 resultó ser decisivo, aunque fue arriesgado. Le permitió ser recompensado por el rey tras la Farsa de Ávila y, de hecho, fue de los pocos nobles enriquistas en ese momento. Tras pasarse a los alfonsinos en 1467, vino la reorientación de nuevo desde 1469 a 1471 hacia Enrique IV y doña Juana, en una delicada coyuntura que le permitió verse premiado en esos años con la ciudad de Coria y con el título de duque de Alba, este en 1472. Mudó de nuevo sus alianzas y en otra decisión importante en 1473-1474 se decantó por el partido isabelino frente al de Juana, Pacheco y los portugueses. Cuando Isabel llegó al trono estaba situado en su círculo de confianza. Luego, la guerra entre 1475 y 1479 le dio al duque de Alba un relieve militar muy destacado, por lo que fue bien recompensado con otros pequeños señoríos en tierras salmantinas y abulenses, siendo ya uno de los más conspicuos nobles de la corte (vid. $\$ 4$ Anexo).

La participación de los Álvarez de Toledo en alianzas internobiliarias fue el instrumento que él, como tantos nobles, utilizó para influir y condicionar a su favor la política regia de concesión de rentas y señoríos. Desde el estudio de L. Suárez, que vio el proceso como una pugna, un tanto esquemática, entre "nobleza» $\mathrm{y}$ "monarquía» ${ }^{9}$ hasta las muy numerosas aportaciones de las últimas décadas, las facciones nobiliarias han sido objeto de atención, no solo desde el punto de vista de las ligas y parcialidades ${ }^{10}$, sino también teniendo en cuenta

9 Suárez Fernández, Luis. Nobleza y monarquía. Puntos de vista sobre la historia política castellana en el siglo XV. Valladolid: Universidad de Valladolid, 1975, 2. ${ }^{\mathrm{a}}$ ed.

10 La bibliografía es muy amplia: VAL VALdivieso, María Isabel del. «Los bandos nobiliarios durante el reinado de Enrique IV». Hispania, 1975, vol. XXXV, n. ${ }^{130}$, pp. 249-293, uno de los trabajos pioneros; ÍDEM. «La farsa de Ávila en las crónicas de la época». En SER Quijano, Gregorio del y MarTín Viso, Ińaki (eds.). Espacios de poder y formas sociales en la Edad Media. Estudios dedicados a Ángel Barrios. Salamanca: 2007, pp. 355-367; Bandos y querellas dinásticas en España al final de la Edad Media. Actas del Coloquio celebrado en la Biblioteca Española de París los dias 15 y 16 de mayo de 1987. Paíis: Biblioteca Española de París, 1991; Morales MuÑIz, Dolores Carmen. «Las confederaciones nobiliarias en Castilla durante la guerra civil de 1465». Anuario de Estudios Medievales, 1988, vol. 18, pp. 455-467. Quien más intensamente se ha dedicado a la cuestión ha sido Quintanilla Raso, María Concepción. "Les confédérations de nobles, et les bandos dans le royaume de Castille au bas Moyen Age. L'exemple de Cordoue». Journal of Medieval History, 1990, vol. 16, n. ${ }^{\circ}$ 2, pp. 165-179; ÍDEM. "Facciones, clientelas y partidos en España en el tránsito de la Edad Media a la Modernidad». En Alvarado, Javier. (coord.). Poder, 
JOSÉ MARÍA MONSALVO ANTÓN

RELACIONES ENTRE NOBLEZA Y MONARQUÍA EN EL SIGLO XV: FACCIONALISMO Y ACCIÓN POLÍTICA DE LOS ÁLVAREZ DE TOLEDO (CASA DE ALBA)

la cultura contractual y las prácticas pactistas que formaban parte del haz de relaciones de la nobleza $^{11}$ y que se desplegaban tanto horizontal como verticalmente ${ }^{12}$.

economía, clientelismo. Madrid: Marcial Pons, 1997, pp. 15-50; ÍDEM. «Integración nobiliaria, violencia y faccionalidad en tiempos de Juan II». En El marqués de Santillana (1398-1458). Los albores de la España Moderna. II. El hombre de estado. Santander: Nerea, 2001, pp. 85-126; ÍDEm. "Relaciones contractuales y propaganda de estatus: "unidad e amistança entre los Grandes del Reyno" ». En Foronda, François y Carrasco Manchado, Ana Isabel (dirs.). Du contrat d'alliance au contrat politique. Cultures et sociétés politiques dans la Péninsule Ibérique de la fin du Moyen Âge. Toulouse: Université de Toulouse II-Le Mirail, 2007, pp. 29-47; ÍDEM. «Para nos guardar e ayudar el uno al otro: pactos de ayuda mutua entre los grandes en el ámbito territorial (el noroeste castellanoleonés, segunda mitad del siglo xv)». Edad Media. Revista de Historia, 2010, vol. 11, pp. 91-121; ÍDEM. «Conflictos entre grandes. De las luchas internobiliarias a los debates interseñoriales». En Nieto Soria, José Manuel (dir.). El conflicto en escenas. La pugna política como representación en la Castilla bajomedieval. Madrid: Sílex, 2010, pp. 59-104. Asimismo, Quintanilla Raso, Títulos, grandes del reino y grandeza en la sociedad política; BECEIRo PITA, Isabel. «Doléances et ligues de la noblesse dans la Castille de la fin du Moyen Âge (1420-1464)». En RucQuor, Adeline (dir.). Genèse médiévale de l'Espagne Moderne. Du refus à la revolte: les résistances. Nice: Université de Nice, 1991, pp. 107-126; Ídem. «Parentesco y alianzas políticas en Castilla (siglo Xv)». En Foronda y Carrasco Manchado (dirs.), Du contrat d'alliance au contrat politique, pp. 9-28; Carceller Cerviño, M. a del Pilar. "Los bandos nobiliarios y la carrera política: ascenso y privanza de Beltrán de la Cueva». Anuario de Estudios Medievales, 2006, vol. 36, n.o 2, pp. 783-801; Sánchez Prieto, Ana Belén. «Un tipo documental fundamentalmente nobiliario: la confederación. Aspectos jurídico-diplomáticos (siglos XV-XvI)». Cuadernos de Estudios Medievales y Ciencias y Técnicas Historiográficas, 1995, vol. 20, pp. 47-63. Estos trabajos citados tienen carácter general, de ámbito "castellano» o de referencia para el tema, pero existen otros muchos que han abordado el problema de las parcialidades nobles en diversos señoríos y regiones y de los que es imposible dar cuenta detallada ahora: por referirnos solo al aspecto geográfico, lo cierto es que son muy numerosos los estudios sobre Andalucía (estudios de Ladero Quesada, Quintanilla Raso, Franco Silva, Devis Márquez, Cabrera Muñoz, entre otros), Galicia (Pardo de Guevara), País Vasco (Díaz de Durana, García Fernández, Dacosta Martínez), Castilla y León (Beceiro Pita, Diago Hernando, Franco Silva, entre otros), Castilla-La Mancha (Jara Fuente, Ortega Cervigón), Extremadura (Gerbet, Lora Serano, Pino García), entre otros.

11 Además de algunos trabajos de Quintanilla Raso citados en la nota anterior, pueden verse los trabajos reunidos en Foronda, François y Carrasco Manchado, Ana Isabel (dirs.). El contrato político en la Corona de Castilla. Cultura y sociedad politicas entre los siglos X al XVI. Madrid: Dykinson, 2008. Asimismo, CARrasCo Manchado, Ana Isabel. Isabel I de Castilla y la sombra de la ilegitimidad. Propaganda y representación en el conflicto sucesorio (1474-1482). Madrid: Sílex, 2006; ÍDEM. «Entre el rey y el reino calladamente está fecho un contrato. Fundamentos contractuales de la monarquía Trastámara en Castilla en el siglo XV». En ForondA, François (dir.). Avant le contrat social. Le contrat politique dans l'Occident médiéval (XII-XV siècle). Paris: Publications de la Sorbonne, 2011, pp. 613-652; Nieto Soria, José Manuel. «La Realeza». En Nieto Soria, José Manuel (dir.). Orígenes de la Monarquía Hispánica: propaganda y legitimación (ca. 1400-1520). Madrid: Dykinson, 1999, pp. 25-62; ÍDEM. «La monarquía como conflicto de legitimidades». En NiETo Soria, José Manuel (dir.). La monarquía como conflicto en la corona castellano-leonesa (c. 1230-1504). Madrid: Sílex, 2006, pp. 13-72; ÍDEM. «Pacto y consenso en la cultura política medieval: algunas perspectivas de análisis». En NIETO Soria, José Manuel y Villarroel González, Óscar (coords.). Pacto y consenso en la cultura política peninsular. Siglos XI al XV. Madrid: Sílex, 2013, pp. 17-40; ÍDEM. «El consenso como representación en la monarquía de la Castilla trastámara: contextos y prácticas». Edad Media. Revista de Historia, 2010, vol. 11, pp. 37-62; FORONDA, François. "La privanza, entre monarquía y nobleza». En Nieto Soria (dir.), La monarquía como conflicto, pp. 73-132; ÍDEM. "Vers un gouvernement de jure dans la Castille du Xv siècle: les contrats de privanza d'Henri IV de Trastamare». En Foronda. y Carrasco Manchado (dirs.), Du contrat d'alliance au contrat politique, pp. 185-244; ÍDEM. "La monarchie élective dans la Castille du Xve siècle. Retour sur la Farce d'Avila (5 juin 1465)». En Peneau, Corinne (dir.). Elections et pouvoirs politiques du VIT au XVIT siècle. Bordeaux-Pompignac: Editions Bière, 2008, pp. 351-381; ÍDEM. El espanto y el miedo. Golpismo, emociones políticas y constitucionalismo en la Edad Media. Madrid: Dykinson, 2013; Quintanilla Raso, María Concepción. "Consenso, pacto, amistad y 
JOSÉ MARÍA MONSALVO ANTÓN

RELACIONES ENTRE NOBLEZA Y MONARQUÍA EN EL SIGLO XV: FACCIONALISMO Y ACCIÓN POLÍTICA DE LOS ÁlVAREZ DE TOLEDO (CASA DE ALBA)

Fue una cuestión muy viva en los reinados de Juan II y Enrique IV. Varios centenares de acuerdos internobiliarios se han conservado. Con ellos se pretendía dar oficialidad a los pactos, dado el valor que se concedía a lo escrito. Pero es seguro que por debajo hubo una intensísima actividad de negociaciones personales, acuerdos verbales y compromisos que nunca fueron oficializados. De modo que es posible que los contratos de alianza, pese a que -hablando en general- son muy numerosos, no constituyan más que la punta del iceberg. El faccionalismo estaba bien inoculado en las venas de la alta nobleza castellana del xv. Y, aunque no sean más que una pequeńa porción de lo que hubo, las escrituras conservadas, básicamente las llamadas "confederaciones pactadas»" ${ }^{13}$, lo ponen en evidencia.

Naturalmente, del cuadro adjunto se deduce la conexión de las luchas faccionarias con la obtención de rentas y patrimonio. Esto no fue un efecto aleatorio, sino que hay que entender que la implicación en bandos y parcialidades fue para los nobles un recurso sistemático. Colocándose al lado de una determinada parcialidad, al comprometer la posición regia mediante una inestabilidad calculada, los nobles contaban con ser recompensados. Había que conseguir que los monarcas se hallasen en situaciones difíciles y vieran la necesidad de contar con apoyos. Había, pues, más un juego de intereses que una defensa de principios políticos. Lógicamente, las parcialidades habían de buscar algunas

seguridad. Escrituras y tácticas nobiliarias en la Castilla del siglo XV». En NiEto Soria y ViLLARroel GonZÁLez (coords.), Pacto y consenso en la cultura política peninsular, pp. 65-91; Franco SiLVA, Alfonso. Los discursos politicos de la nobleza castellana en el siglo XV. Cádiz: Universidad de Cádiz, 2012; Villarroel González, Óscar. «Negociación y representación del consenso: los conflictos de época de Juan II de Castilla». En Nieto Soria y Villarroel González (coords.), Pacto y consenso en la cultura politica peninsular, pp. 237-259; ÍDem. Juana la Beltraneja. La construcción de una ilegitimidad. Madrid: Sílex, 2014.

12 Como seńala una gran especialista: «Los grandes seńores en la Castilla del siglo xv acuñaron un sistema de relaciones por el que quedaban insertos en tupidas redes de lazos internobiliarios, tanto de signo horizontal, basados en la igualdad de estatus, como de carácter vertical, fundamentados en relaciones desiguales, de preeminencia-dependencia»; Quintanilla Raso, «Consenso, pacto, amistad y seguridad», p. 65. Los pactos importaban por el hecho de existir, más allá del contenido. Se ha destacado que el consenso que subyacía en estos pactos era una forma de representación; NIETO SoRIA, «El consenso como representación» y Villarroel GonZÁLEZ, «Negociación y representación del consenso».

13 Por utilizar un comodín archivístico, aunque el término es muy impreciso. Así son denominadas muchas de estas cartas en la edición clásica del catálogo de la monumental Colección Salazar. En concreto, se agrupa este tipo de documentos en dos manuscritos. Aunque hoy día hay un catálogo de la Colección Salazar en pdf en la RAH, vid. la referencia a "confederaciones pactadas» en VARGAS-ZÚNíIGA y MonTERo DE Espinosa, Antonio de y Cuartero y Huerta, Baltasar (eds.). Índice de la Colección de don Luis de Salazar y Castro. Tomo XXV, Documentos de Estado y Gobierno de España y confederaciones entre personajes ( $K-12$ al K-37). Madrid: Real Academia de la Historia, 1960, concretamente, K-36 (66 documentos de los ańos 11911452) y K-37 (145 documentos de los años 1444 a 1522 y otros posteriores), pp. 355-422 de esa edición del índice. Pero ni todos esos documentos eran propiamente pactos entre nobles ni incluyen estas reseńas todos los que hay: En M-9, por ejemplo, se conservan otras escrituras, cédulas y privilegios donde también se hallan pactos y alianzas entre nobles semejantes a los de esos dos ms. indicados. En los fondos documentales de la BN y del AHN, sección Nobleza, sobre todo, se conservan otros documentos. La referencia archivística de "confederaciones nobiliarias», que puede rastrearse en los grandes fondos-Osuna, Frías, por ejemplo- es suficiente muestra de la extensión del fenómeno durante el siglo xv. Los fondos autónomos de otras casas, como Alburquerque o Alba, entre otras, contienen también este tipo de documentos. Muchos de ellos, en distintas épocas y publicaciones, se hallan editados. 
JOSÉ MARÍA MONSALVO ANTÓN

RELACIONES ENTRE NOBLEZA Y MONARQUÍA EN EL SIGLO XV: FACCIONALISMO Y ACCIÓN POLÍTICA DE LOS ÁLVAREZ DE TOLEDO (CASA DE ALBA)

justificaciones -la tiranía de Álvaro de Luna, el influjo excesivo en la corte de Beltrán de la Cueva, la causa alfonsina, o los derechos sucesorios de Juana la Beltraneja frente a Isabel... ${ }^{14}$-, además de argumentos como el bien común o la paz y sosiego de nuestros regnos, al tiempo que todos decían servir ${ }^{15}$ la causa del rey. No hay por qué descartar estos propósitos como motivaciones. Pero hay que buscar además intereses no reconocidos que no se hacían explícitos. Los nobles necesitaron el faccionalismo para obtener más poder, mercedes, rentas y señoríos. Y para eso era preciso que el statu quo fuese alterado por las concesiones regias. Por eso generar conflicto era provechoso. Y eso se traducía en formar alianzas potentes para condicionar las decisiones de los reyes, para obligarles a ceder. Este era el engranaje.

Normalmente no se hacían explícitas las intenciones de fondo. Sabemos que no son coincidentes los comportamientos públicos, los privados y los ocultos. Pero lo cierto es que algún atisbo de este oportunismo interesado y no confesado se desliza en la documentación.

En el pacto firmado entre el almirante Fadrique, Juan Pacheco, el príncipe Enrique y los Alba en 1443, los dos primeros al rubricar en 21 de junio en Alba este acuerdo señalaban: «está firmada e contratada amistança e confederaçión con vos, don Gutierre, arçobispo de Toledo, e don Ferrand Álvarez, conde de Alva (...) servir e seguir al dicho señor prínçipe. E su señoría de nos fazer merçedes, defender e anparar e favoreçer ${ }^{16}$. Favorecer, conceder mercedes. Este es el juego, una forma más del característico do ut des, que solo un marco de inestabilidad funcional propiciado por los nobles hacía posible en aquel contexto. «E de vos ayudar por todas mis fuerças con el dicho rey para que vos favoreze [favorezca] e faga merçedes», decía la reina María en $1441^{17}$. Se confiscaban bienes a enemigos o se sacaban del realengo para concederlos a los amigos. Amistad y enemistad eran lenguaje habitual de los pactos ${ }^{18}$. En 1445 lo decía Juan II al confirmar que había favorecido al conde de Alba y a Luna con los bienes de su contador mayor Fernán López de Saldaña, seguidor de los infantes de Aragón ${ }^{19}$. Por el contrario, como ejemplo

14 Vid. referencias en los títulos citados en las notas 10-12 y en las crónicas castellanas.

15 Resulta muy interesante el léxico que empleaban unos y otros. No hay ocasión aquí para detalles. Me remito a un trabajo, complementario de este, titulado «El lenguaje del poder en la Castilla del siglo xv: léxico político y alianzas nobiliarias de los Álvarez de Toledo (Casa de Alba)». En Carrasco Manchado, Ana Isabel. El historiador frente a las palabras. Lenguaje, poder y politica en la sociedad medieval. Nuevas herramientas $y$ propuestas. Lugo: Axac (en prensa).

16 DCasaAlba-Salamanca, doc. 30.

17 ADA, c.2.49, DCasaAlba-Salamanca, doc. 25. La reina María firmaba una confederación con un pequeño círculo entre el que estaba el conde de Alba. La reina se comprometía a interceder ante su marido, Juan II, para que este agradeciese con mercedes el paso dado por personas tan estrechamente vinculadas poco antes a Álvaro de Luna.

18 Entre otros, vid. Quintanilla Raso, «Relaciones contractuales y propaganda de estatus»; CARRASco Manchado, Ana Isabel. «Léxico político en el Seguro de Tordesillas: conflicto, pactos y autoridad real». En Foronda y Carrasco Manchado (dirs.). Du contrat d'alliance au contrat politique, pp. 85-137.

19 Recién derrotados: «Por quanto por las cosas fechas e cometidas en mi deserviçio e escándalo e daño de mis rregnos por Fernand López de Saldaña, mi contador mayor que fue, en favor del rey don Iohán de Navarra e del infante don Enrrique [señala Juan II, que dice que los dio a Luna y al conde de Alba]... Por ende, yo por la presente apruevo e confirmo la merçed que yo fize a los dichos condestable e conde de Alva» Doc.Álvaro de Luna, doc 104; DCasaAlba-Salamanca, doc. 31. 
JOSÉ MARÍA MONSALVO ANTÓN

RELACIONES ENTRE NOBLEZA Y MONARQUÍA EN EL SIGLO XV: FACCIONALISMO Y ACCIÓN POLÍ́TICA DE LOS ÁlVAREZ DE TOLEDO (CASA DE ALBA)

de pérdida de bienes por efecto de una parcialidad, vemos cómo en octubre de 1448, a los pocos meses de estar en prisión Fernando Álvarez de Toledo, Juan II concedía a Juan Pacheco la villa de Barco de Ávila ${ }^{20}$.

Vemos también muy abiertamente cómo, cuando García Álvarez de Toledo se pasó al bando de los alfonsinos en septiembre de 1467 -no mucho después de firmar un pacto con el otro bando ${ }^{21}$, recibió inmediatamente promesas de los cabecillas del partido del rey Alfonso, Pacheco y Carrillo, de recibir alguna ciudad importante ${ }^{22}$; y poco después, en noviembre de ese año, el joven rey Alfonso confirmaba todas las mercedes que el conde tuviera. ¿Por qué? Muy sencillo: «venistes a me servir e dexastes de seguir al dicho don Enrrique, mi anteçesor» ${ }^{23}$. El interés, el esperado pago por parte de sus nuevos aliados, eso había movido el compromiso con la nueva parcialidad ${ }^{24}$.

Podrían ponerse más ejemplos, pero es suficiente para entender el mecanismo esencial de recompensa por estar en el bando vencedor o de posible pérdida si la situación era la inversa. En el caso estudiado basta ver el cuadro de acontecimientos para hacer un balance, es claro que muy positivo para el linaje, de lo ganado entre 1430 y 1479.

Es importante tener en cuenta este mecanismo del faccionalismo como modo de allegar rentas, títulos y señoríos. Los nobles colaboraron entre sí haciéndose fuertes a través de sus alianzas, obtuvieron del poder regio concesiones tras colocarle en situación de dificultad. Si se aplica la teoría de los juegos, la acción colectiva de los nobles encajaría en algunos tipos de juegos «de cooperación», o "de coalición», aquellos en los que los jugadores que actúan coordinadamente no salen perjudicados. La idea de equilibrio y los modelos de negociación que, por ejemplo, el matemático John Nash propuso a mediados del siglo xx serían perfectamente aplicables a estas situaciones. Al fin y al cabo, las decisiones de cada jugador-linaje nobiliario tenían en cuenta las decisiones tomadas en el tablero por los otros jugadores-otros linajes nobles. Al tratarse de juegos de cooperación, los jugadores buscaban actuar coaligados para no salir perjudicados y poder presionar. Naturalmente, siempre según el contexto de poderes y potencial de cada linaje.

20 AHN, Nobleza, Frías, C.659, D.25. No tuvo efecto finalmente.

21 En concreto en marzo de 1466. Firmaban entonces una confederación Beltrán de la Cueva, el marqués de Santillana Diego Hurtado de Mendoza, su hermano Pedro González de Mendoza y el conde de Alba, RAH, SyC, M-9, fols. 404v-405; AHN, Nobleza, Osuna, C.1860, D.16. Al pacto se unía después la reina doña Juana, AHN, Nobleza, Osuna, C.1860, D.15.

22 Toro o Ciudad Rodrigo. Y, «fasta quel dicho señor conde de Alva sea pagado por el dicho señor rrey don Alfonso e por los dichos señores grandes e perlados de su partido», Carrillo dejaba en prenda su villa de Puente del Arzobispo en septiembre de 1467, DCasaAlba-Salamanca, doc. 49.

23 «E porque al tienpo que vos, el dicho conde, venistes a me servir e dexastes de seguir al dicho don Enrrique, mi anteçesor, entre las otras cosas que por mí e por los grandes de mis rreynos que conmigo estavan, vos fueron prometidas e juradas, fue capitulado que asý a vos commo a los vuestros yo mandase tornar e rrestituyr en todos vuestros ofiçios e vasallos e rrentas e maravedís e otra qualesquier cosas que en mis rreynos vos e ellos toviésedes, e vos mandase confirmar todo ello», 1467, noviembre, 3; DCasaAlba-Salamanca, doc. 50.

24 El cambio de bando fue muy mal visto por muchos. El cronista Diego Enríquez del Castillo hacía ver la vergonzosa venalidad del de Alba: «era caballero movible, e de poca firmeza, más amigo del interese que no de la honra (...) descían que se avía vendido en pública almoneda (...), ¿quién da más por el conde de Alva, que se vende a cada cantón?, ¿ay algunos que lo pongan en prescio?»; Crónica Enrique IV, p. 166. 
JOSÉ MARÍA MONSALVO ANTÓN

RELACIONES ENTRE NOBLEZA Y MONARQUÍA EN EL SIGLO XV: FACCIONALISMO Y ACCIÓN POLÍTICA DE LOS ÁLVAREZ DE TOLEDO (CASA DE ALBA)

Dentro de estas analogías, señalemos también que la lógica del faccionalismo no se apoyaba en un «juego de suma cero». Tendencialmente los nobles salían ganando. Pudo haber derrotados individuales, pero desde el punto de vista colectivo la alta nobleza salió favorecida. Hay un par de razones que lo explican. La primera hace referencia al protocolo de gestión de las luchas faccionarias. Es cierto que algunos linajes "perdieron», como los Dávalos, o las posesiones «castellanas» de los infantes tras 1445, o Álvaro de Luna en 1453 ... Pero otros nobles -le pasó al de Alba y a otros muchos- con sus malas decisiones, errores o mala suerte no perdían en la misma medida aquello que ganaban con sus opciones acertadas o en episodios afortunados y de bandos vencedores. A veces los nobles se beneficiaban del doble juego de mantener alianzas con unos y otros, ganando en cualquier caso, como el conde de Alba en 1460, 1464 y $1467^{25}$. Pero es que además se solía premiar muy generosamente a los aliados en las situaciones más difíciles, como por ejemplo al de Alba cuando apoyó al rey en 1430 o en 1465, cuando el grueso de la nobleza se alineaba en la causa contraria. En cambio, las derrotas no conllevaban pérdidas proporcionales: no siempre se confiscaban los bienes o se castigaba a los perdedores, ya que a veces convenía sellar las paces o atraerlos a su lado; y así el de Alba no perdió tanto a la postre, pese a estar en el lado perdedor en 1440-1443 o en 1448-145426. La segunda razón, que sustenta la anterior, es que el faccionalismo obtuvo réditos de un fondo que no era invariable. Al contrario: las rentas fiscales del país fueron crecientes, el estado central las detraía con eficacia y traspasaba a los nobles; y el realengo menguante -entre Enrique II y Enrique IV en Castilla se redujo a la mitad-servía para compensar los apoyos, las paces, las alianzas, en definitiva, todos los dispositivos que el faccionalismo ponía en marcha y que terminaban en concesiones de los reyes a los nobles. Cuando el faccionalismo fue fuerte, las rentas del estado central y el realengo sufrieron más. Por eso tendencial y colectivamente los nobles ganaron con este recurso político.

\section{DIVERSIDAD Y CONDICIONES DE LAS ALIANZAS Y PACTOS}

Los Álvarez de Toledo se relacionaban vertical y horizontalmente con otros nobles, con el rey, con sus vasallos y con los territorios realengos próximos ${ }^{27}$. En el caso del rey, por parte de este habría que mencionar la concesión de mercedes, comisión al noble para actuar militarmente en una ciudad o zona, así como el ejercicio de un poder imperativo o coercitivo ${ }^{28}$. Por lo que respecta a las relaciones hacia abajo, habría que

25 Vid. Anexo. El pacto del conde de Alba con Juan Pacheco en julio de 1467 es un buen ejemplo del doble juego (vid. infra, nota 51). Es posible que también hiciera doble juego en 1469-1471 y en 1472-1473.

26 Hubo casos más claros que el de los Alba. Los Estúniga, pese a haber sido tan enemigos durante una década de Isabel, tras titubeos de esta en 1475-1476, al final fueron perdonados y reconocidos en muchas de sus posesiones - perdieron Arévalo, pero no Béjar o Plasencia y se les hizo duques-, en 1477 (AGS, RGS, leg. 147707, 309), sencillamente porque se prefirió la tranquilidad o pacificación a la venganza.

27 Vid. la figura «Relaciones y alianzas políticas en el esquema de poder nobiliario: los Álvarez de Toledo en las parcialidades y acciones de pacificación».

28 Por poner solo un ejemplo, la decisión de apresar al conde de Alba en 1448, DCasaAlba-Ávila, doc. 23. 
JOSÉ MARÍA MONSALVO ANTÓN

RELACIONES ENTRE NOBLEZA Y MONARQUÍA EN EL SIGLO XV: FACCIONALISMO Y ACCIÓN POLÍTICA DE LOS ÁLVAREZ DE TOLEDO (CASA DE ALBA)

mencionar obviamente las relaciones con los habitantes de sus señoríos, sus vasallos de Valdecorneja, Alba y otros señoríos, aunque también la intervención en el realengo, que en el caso de los Alba se concretó en actuaciones en las ciudades de Ávila, Ciudad Rodrigo y Salamanca ${ }^{29}$.
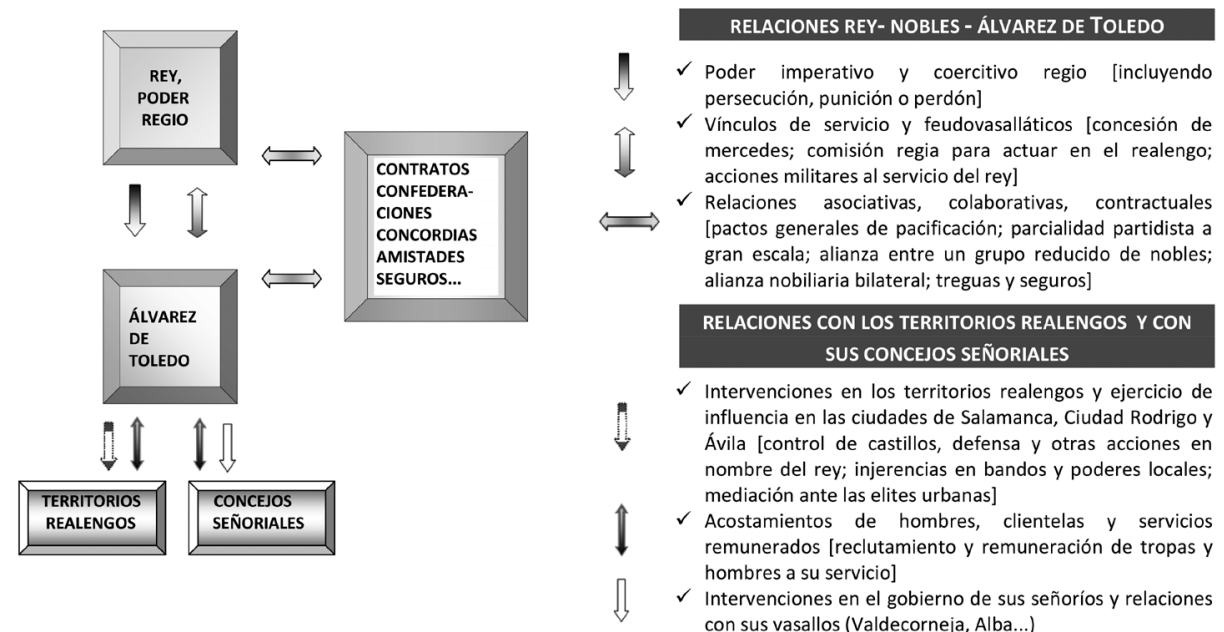

Relaciones y alianzas políticas en el esquema de poder nobiliario: los Álvarez de Toledo en las parcialidades y acciones de pacificación

No nos centraremos aquí en estos vínculos verticales, sino en las relaciones asociativas, colaborativas y contractuales. Primero puede establecerse una sucinta tipología, sin entrar en demasiados detalles ya que existe el cuadro cronológico, y luego se podrán destacar los contenidos habituales de los pactos, según las cláusulas que solían contener.

Un primer tipo de alianzas fueron las de pacificación de carácter general. Este tipo de pactos fueron relativamente frecuentes desde 1437-1438, desde el momento en que se hizo fuerte una liga nobiliaria contraria a Álvaro de Luna. Fernando Álvarez de Toledo participó en varios de estos acuerdos. No tuvo aún un papel destacado en el llamado

29 «Esferas de poder nobiliario y relaciones con el poder regio en la Salamanca medieval: de la caballería concejil al duque de Alba». En Costa, Adelaide (coord.). Conflicto político: lucha y cooperación. Ciudady nobleza en Portugal y Castilla en la Baja Edad Media (coloquio Lisboa, dic. 2015). Lisboa (en prensa). Sobre la influencia altonobiliaria en ámbitos urbanos, podrían ponerse muchos casos. Por remitirme, a modo de ejemplo, a una ciudad castellana de la Meseta, Cuenca, con su entorno regional, la bibliografía es abundante; vid., entre otros: Quintanilla Raso, María Concepción. "Política ciudadana y jerarquización del poder. Bandos y parcialidades en Cuenca». En la España Medieval, 1997, vol. 20, pp. 219-250; Ortega Cervigón, José Ignacio. «Lazos clientelares y bandos nobiliarios conquenses durante el siglo xv». Espacio, Tiempo y Forma. Serie III, Historia Medieval, 2007, vol. 19, pp. 211-231; Jara Fuente, José Antonio. "Çercada de muchos contrarios. Didáctica de las relaciones políticas ciudad-nobleza en la Cuenca del siglo Xv». Edad Media. Revista de Historia, 2013, vol. 14, pp. 105-127; SÁnchez Benito, José María. «Nobleza territorial y política ciudadana en el siglo xv (Los concejos del área del Tajo)». Espacio, Tiempo y Forma. Serie III, Historia Medieval, 2014, vol. 27, pp. 463-502. 
JOSÉ MARÍA MONSALVO ANTÓN

RELACIONES ENTRE NOBLEZA Y MONARQUÍA EN EL SIGLO XV: FACCIONALISMO Y ACCIÓN POLÍTICA DE LOS ÁLVAREZ DE TOLEDO (CASA DE ALBA)

Seguro de Tordesillas, un complejo proceso de negociación concretado, sin éxito, en varias vistas acaecidas en Tordesillas -y otras localidades- entre junio y agosto de $1439^{30}$. En los siguientes intentos de pacificación general participó Fernando Álvarez de Toledo. El rey en octubre de 1439 en Castronuño con su licencia dio vía libre para que Álvaro de Luna y sus enemigos firmaran una confederación pacificadora. En ella estuvo el conde de Alba ${ }^{31}$.

Puede considerarse la llamada Sentencia de Medina de julio de 1441 otro intento general de pacificación. Pero en este caso sostenido sobre la derrota previa de Álvaro de Luna poco antes. La sentencia establecía el apartamiento de Luna y la anulación -con excepciones- de las mercedes otorgadas desde 1438. Fue redactada por cuatro personas: la reina dońa María, el príncipe don Enrique, el almirante don Fadrique y Fernando Álvarez de Toledo ${ }^{32}$.

El conde formó parte de otros pactos de corte pacificador, aunque no hubo, sobre todo ya en el reinado de Enrique IV, acuerdos generales que no fueran levantados sobre la derrota de alguna parcialidad. No obstante, sí participó en negociaciones. Y su nombre aparece en algunos intentos de pacificación o pactos entre rivales. Uno de ellos tuvo lugar en la primavera de 1464 , siendo ya el nuevo conde don García ${ }^{33}$. Otros intentos de pacificación se produjeron a los pocos meses. Enrique IV, su hija, Beltrán de la Cueva y el clan Mendoza se veían obligados a negociar con la liga liderada por Pacheco y Carrillo ${ }^{34}$. El conde de Alba puso su firma en varios de los principales pactos

30 Hay abundante documentación archivística sobre el episodio. Pero también un escrito en forma de crónica. El conde de Haro, que fue el encargado de organizar las vistas que deberían haber llevado a la paz entre Álvaro de Luna y los infantes de Aragón, dejó un valioso testimonio. Gómez Redondo señala que bien podría ajustarse al género de crónica particular y biografía, aunque contenía otros registros diferentes y una interesante «malla documental» de escritos, réplicas, diálogos y fablas varias incluidas en el texto. Este ha sido editado -según un impreso del siglo XviI- por Marino, Nancy F. El «Seguro de Tordesillas» del conde de Haro don Pedro Fernández de Velasco. Valladolid: Universidad de Valladolid, 1992. Hace unos años varias ponencias se ocuparon del episodio. Las más directamente relacionadas fueron las siguientes: GómEZ Redondo, Fernando. «Elocución y diplomacia: rivalidades culturales en Tordesillas». En Foronda y CARrasco Manchado, (dirs.). Du contrat d'alliance au contrat politique, pp. 49-64; Rábade Obradó, María del Pilar. "Confederaciones, seguros y pleitos homenajes: el contexto documental del Seguro de Tordesillas». En Foronda y Carrasco Manchado, (dirs.). Du contrat d'alliance au contrat politique, pp. 65-84; Carrasco Manchado, «Léxico político en el Seguro de Tordesillas», pp. 85-137.

31 RAH, SyC, M-9, fols. 276-279v. Fernando Álvarez de Toledo, próximo a Luna, fue uno de los once firmantes nobles, incluidos los dos infantes de Aragón Juan y Enrique, y algunos eclesiásticos. Firmaba por su parte Álvaro de Luna. Unos y otros se comprometían a ser «siempre buenos fieles leales y verdaderos amigos».

32 Este último hasta hacía poco gran valedor del condestable. La sentencia fue redactada en Medina entre los días 3 y 7 de julio de 1441. El conde de Alba firmó este último día. Y la firma del rey Juan II, garante último de la Sentencia, fue el 9 de ese mes. La decisión fue considerada tan importante como para ser reproducida en algunas crónicas, RAH, SyC, leg. 27, carp. 6, n. ${ }^{\circ} 3$; Crónicas BAE II. Juan II, II, pp. 598-603, Crónica del Halconero, ed. Carriazo, pp. 421-432.

33 AGS, PTR, leg. 11, doc. 79; PTR, leg. 7, doc. 110.

34 Sobre estos dos personajes Franco Silva, Alfonso. Juan Pacheco, privado de Enrique IV de Castilla. La pasión por la riqueza y el poder. Granada: Universidad de Granada, 2011; Ídem. El arzobispo de Toledo. Alonso Carrillo: un prelado belicoso del siglo XV, apasionado por la riqueza y el poder. Cádiz: Universidad de Cádiz, 2014. 
JOSÉ MARÍA MONSALVO ANTÓN

RELACIONES ENTRE NOBLEZA Y MONARQUÍA EN EL SIGLO XV: FACCIONALISMO Y ACCIÓN POLÍTICA DE LOS ÁLVAREZ DE TOLEDO (CASA DE ALBA)

que, entre el 28 de septiembre y el 5 de diciembre ${ }^{35}$, obligaban al rey a ceder y que acabarían fructificando en la Sentencia de Medina -redactada en los últimos días de 1464, promulgada ya en enero de $1465^{36}$-, pero ya en una situación de triunfo de la liga y expulsión de la corte de Beltrán de la Cueva.

Un segundo tipo de alianza era la entrada en una parcialidad partidista a gran escala, pero no para la pacificación sino para el hostigamiento a los enemigos. Las grandes parcialidades adquirían al final esta fisonomía. Las más significativas fueron las que condujeron a las dos batallas de Olmedo, a la caída del condestable o a la guerra entre Enrique IV y sus hermanastros. No es necesario referirse ahora a estos grandes enfrentamientos, de los que dan cuenta las crónicas. También en estas grandes coaliciones o grandes facciones del reino encontramos a los Álvarez de Toledo ${ }^{37}$.

Un tercer tipo de alianza se daba entre nobles, pero a pequeña escala. Los firmantes eran unos pocos. Los Álvarez de Toledo firmaron varios acuerdos de esta índole.

Tras los reveses de Luna frente a los infantes, el 30 de junio de 1441 firmaban una confederación el conde, su tío don Gutierre, la reina dońa María y Lope de Barrientos ${ }^{38}$.

La confederación firmada el 21 de junio de 1443 entre el príncipe, Juan Pacheco, el almirante, don Gutierre de Toledo y su sobrino el conde de Alba constituía un núcleo importante de la causa contra los infantes ${ }^{39}$. Álvaro de Luna se integraría en el grupo. El 25 de agosto de 1444 se documenta otra alianza entre el condestable, el almirante Fadrique y el conde de Alba, que configuró un bastión frente a los infantes ${ }^{40}$.

Hacia 1456 el conde de Alba parece haberse confederado con un pequeño grupo $^{41}$. El conde de Alba formó también parte de otro pequeño grupo de nobles con quienes el rey Juan de Aragón y Navarra firmó una alianza en agosto de $1460^{42}$. Y este mismo trastámara aragonés, enfrentado a Enrique IV, firmaba una confederación, en algún momento de 1464, con un puñado de nobles, entre ellos el conde de Alba, pero también Alonso Carrillo, el conde de Benavente, el almirante Fadrique y otros nobles de primera línea ${ }^{43}$.

35 Dos documentos de 28 de septiembre de 1464, Memorias Enrique IV. Colección Diplomática, docs. 97 y 98; capitulaciones del 30 de noviembre entre Cigales y Cabezón, Memorias Enrique IV. Colección Diplomática, doc. 102, AHN, Nobleza, Frías, C.15, D.4-5 Villarroel González, Juana la Beltraneja, pp. 264-267; seguro a Beltrán de la Cueva para facilitar su salida de la corte, Memorias Enrique IV. Colección Diplomática, doc. 103; propuestas de peticiones al rey para la sucesión y el gobierno del reino, presentadas en Cigales el 5 de diciembre, que incluían otras cuestiones sobre política religiosa, económica y asuntos sobre la administración general. AHN, Nobleza, Frías, C.9, D.3; CODOIN, t. XIV, pp. 369-395.

36 Memorias Enrique IV. Colección Diplomática, doc. 109, pp. 355-479.

37 Vid. el Cuadro de acontecimientos.

38 ADA, c.2.49, DCasaAlba-Salamanca, doc. 25.

39 DCasaAlba-Salamanca, doc. 30.

40 Ya en el camino hacia la derrota de estos, Doc. Álvaro de Luna, doc 101.

41 Según parece por el seguro y amistad que el rey otorgaba a Juan Pacheco y su hermano Pedro Girón, al arzobispo de Sevilla, al almirante don Fadrique y al propio conde, Paz y Melia, Ilustraciones, doc. 5, pp. $10-12$.

42 Paz y Melia, Ilustraciones, doc. 8, pp. 13-19. El marqués de Santillana Diego Hurtado de Mendoza y su hermano, el obispo Pedro de Mendoza, el almirante don Fadrique y el conde de Paredes Rodrigo Manrique.

43 AHN. Nobleza, Osuna, C.445, D.3. 
JOSÉ MARÍA MONSALVO ANTÓN

En esos ańos, los de mayor debilidad de Enrique IV, el conde don García aparece muy implicado en varios pactos a pequeña escala. Puede apreciarse cómo, tras la Farsa de Ávila, firmaba el 15 de julio de 1465 un acuerdo con Beltrán de la Cueva, Pedro de Mendoza y Gómez Suárez de Figueroa, intentando los tres primeros ganar a la causa enriquista a este último ${ }^{44}$. Se aprecia igualmente el movimiento de unos pocos nobles en la confederación de marzo de 1466 entre Beltrán de la Cueva, Diego Hurtado de Mendoza, su hermano el obispo Pedro de Mendoza y el conde de $\mathrm{Alba}^{45}$. El respaldo de la reina Juana a este pequeño grupo de leales en una confederación e amistad que ella tutelaba por entonces reforzaba la posición de este grupo en el bando enriquista, entonces en situación difícil ${ }^{46}$.

Una cuarta modalidad sería la de los pactos bilaterales. Se encuentran algunos en el reinado de Enrique IV. En abril de 1462 el conde aparece en un pacto con Juan II de Aragón y Navarra ${ }^{47}$. Podría considerarse como confederación y amistad la firmada por Enrique IV y su esposa Juana en junio de 1464 en favor del conde de Alba ${ }^{48}$. También lo sería la firmada por la reina Juana y el conde de Alba en marzo de $1466^{49}$.

Más claramente bilaterales, y en este caso efectuadas entre nobles estrictamente, fueron las confederaciones y amistades que firmó el conde con Juan Pacheco. La de agosto de 1464, en la que el conde le decía al marqués de Villena que «siempre vos seré fiel e leal e verdadero amigo ${ }^{50}$, se forjó seguramente a escondidas de Enrique IV, que poco antes había asegurado al conde. Y con Pacheco también sellará un pacto bilateral el 1-3 de julio de 1467, ya en plena guerra y cuando el bando alfonsino era liderado por Pacheco y Carrillo ${ }^{51}$.

44 Se aprecia bien el juego de promesas y recompensas que, en nombre del rey, ofrecía al recién adherido el grupo de confianza de Enrique IV: «nos, don Beltrán de la Cueva, duque de Alburquerque, conde de Ledesma, e don García de Toledo, conde de Alva, e don Pedro González de Mendoza, obispo de Calahorra, todos del Consejo del Rey, nosotros, por razón que vos don Gómez Xuárez de Figueroa, conde de Feria, del Consejo del dicho señor rey, fizisteis pleito e omenage a su señoría de lo servir e seguir daquí adelante en todos los días de una vida contra todas las personas del mundo. E asimesmo su señoría vos seguró e prometió por su fe e palabra real que serbiéndole vos bien e fielmente miraría por vos e por vuestros (sic) honra e casa e estado y que él non tenía dado nin daría vuestro condado nin cosa alguna de lo vuestro a persona alguna nin permitiría nin daría lugar que por vos le serbir e seguir cosa alguna de lo vuestro vos fuesse tomado nin que otro dańo alguno en vuetra tierra fuesse fecho; antes para lo resistir vos daría y mandaría dar todo fauor (...) que siruiendo vos el dicho conde de Feria al dicho seńor rey bien e lealmente segund en el dicho pleito omenage que así a su señoría fecistes se contiene, que nosotros ternemos manera con el dicho señor rey e trauajaremos con su seńoría a todo nuestro leal poder por que lo así cumpla e tenga e guarde segund es en la manera que en la fe e seguridad que así su alteza vos dio se contiene. E que, si contra ello su seńoría fuere, o viniere, nosotros lo non consentiremos; antes nos juntaremos con vos e vos daremos todo fauor por nuestras personas e con nuestras gentes para lo resistir e non dar lugar a ello», RAH, SyC, K-37, fol. 30-30v.

45 RAH, SyC, M-9, fols. 404v-405; AHN, Nobleza, Osuna, C.1860, D.16; Morales Muñiz, «Las confederaciones nobiliarias", doc 3.

46 AHN, Nobleza, Osuna, C.1860, D.15.

47 Documentos escogidos, p. 5. Sobre la singularidad de la presencia del rey en los acuerdos, vid. infra.

48 Se solapa la alianza propiamente dicha con una carta de seguro. Vid. infra, nota 57.

49 Documentos escogidos, p. 7. Se inscribía en una alianza más amplia con los Mendoza y Beltrán de la Cueva, AHN, Nobleza, Osuna, C.1860, D.15.

50 AHN, Nobleza, Frías, C.13, D.14.

51 En este caso se trata de un pacto revelador del funcionamiento de las parcialidades. El conde de Alba todavía militaba oficialmente en la parcialidad enriquista. El pacto implicaba que, si los alfonsinos ganaban, el marqués de Villena, líder de este partido, aseguraría protección al conde de Alba: "por quanto vos 
Una quinta modalidad, aunque especial, era la carta de tregua e seguro. Estas cartas garantizaban mantener a salvo al beneficiario, sus parientes y sus bienes. Garantía sobre personas y bienes que alcanzó en las cartas que otorgaba el rey su modo más genuino ${ }^{52}$, si bien los líderes nobiliarios, sin esa condición regia, daban también estas seguridades.

En los citados acuerdos de Castronuño de octubre de 1439 se concretaba, el día 20 de ese mes, que los firmantes del pacto aseguraban a sus respectivos rivales: los partidarios de Juan de Navarra a Luna y viceversa ${ }^{53}$. También estuvo presente el conde en los seguros de abril de $1440^{54} \mathrm{y}$ en los de septiembre de $1441^{55}$. En alguna otra ocasión el conde de Alba intervenía en representación de Juan II en las treguas o paces que este firmó con Juan de Navarra y su partido. En concreto, el 28 de octubre de 1444 se llegó a un acuerdo -no sería duradero- bajo la fórmula de tregua o contratos de paz entre Castilla y Navarra. Figuraba Fernando Álvarez de Toledo, camarero mayor del príncipe don Enrique ${ }^{56}$.

el dicho señor conde seguides la opinión del rey don Enrique, e podría acaescer según la diuisión e guerras en que todos andamos que la parte del dicho rey don Enrique fuesse vencida o se perdiesse, o vos el dicho señor conde, seguiendo a dicha opinión vos matassen, o fuessedes preso e fuésedes preso e tomado lo vuestro o parte dello, por ende yo el dicho marqués de Villena vos doy mi fe e aseguro e prometo que en qualquier caso de los susodichos me porné por vos como por mí mesmo e vos seré verdadero amigo e guardaré vuestra persona, vida, honra, casa y estado e de vuestros fijos, así como la propia mía. E si preso fuerdes con toda verdad trauajaré por vos delibrar. E si lo non podiere facer me juntaré con la dicha condesa vuestra muger e con vuestros fijos con mi persona e casa e con todas las más fuerzas que yo podiere, a demandar la dicha vuestra liuertad e restituçión al dicho estado que oy tenéis o touierdes de aquí adelante si vos ouiere seído quitado». Era una manera de protegerse fuese cual fuese el resultado de la contienda. Aparte de ello, Juan Pacheco ofrecía la posibilidad de cambio de bando, algo que, en efecto, se produjo poco después: «Iten vos aseguro e prometo que si entrar quisierdes en el partido del rey don Alfonso en que yo estoy vos faré recevir e que se vos faga aquel partido e honra que a vuestra persona y estado se deva facer e seades guardado en él como yo mesmo. E si esto no bastare a poder acauar con el dicho señor rey, que yo así signo e con los del su partido me juntaré con vos con mi casa y estado e seguraré el partido que vos seguierdes, así como vos mesmo lo seguiréis». El acuerdo, aparte de otras solemnidades habituales, incluía una cláusula muy significativa, el secreto, lo cual tiene lógica ya que era un acuerdo preventivo y de protección mutua en cualquier desenlace: «yo el dicho marqués de Villena juro e prometo de guardar secreto de todo lo susodicho e de cada cosa e parte dello e de todas las cosas que daquí adelante se communicaren e fablaren entre nosotros e non las descobriré nin revelaré por escripto nin por palabra nin por señas, nin por mensagero nin por otra vía nin manera alguna que sea a ninguna persona nin personas de qualquier estado o condición que sean", RAH, SyC, K-37, fols. 39v-40. Copia posterior. Y N-44 fols. 454 y 455 (212-213 en numeración moderna). Es interesante comprobar que este tipo de acuerdos eran subyacentes a las alianzas más o menos conocidas y abiertas. Representaban un plano de pactos ocultos, privados, útiles si las circunstancias eran adversas en el futuro. Ese era el doble juego de los nobles en muchas ocasiones. En este propio acuerdo con el conde de Alba salía a relucir otra escritura privada que Juan Pacheco había firmado con Álvaro de Estúñiga, el aliado oficial en ese caso, y el propio marqués, el aliado secreto, daba por no anulado dicho pacto al firmar el del conde de Alba: «E porque yo el dicho marqués de Villena tengo çierta escritura de amistad con el conde de Plasencia, la qual se entienda que queda saluada, non embargante que a esta no estorua», ibid.

52 El rey añadía a la voluntad de protección física, familiar y patrimonial la capacidad de hacerlo en virtud de su poderio absoluto. Vid. infra.

53 Doc.Álvaro de Luna, doc. 64. El 29 de ese mes Juan II escribía una carta donde figuraba una amplia relación de miembros del clero y nobles -entre ellos Fernán Álvarez de Toledo y su tío don Gutierre- poniendo bajo su protección real a Álvaro de Luna, Doc.Álvaro de Luna, doc 66.

54 Doc.Álvaro de Luna, docs. 76 y 79.

55 RAH, SyC, M-9, fols. 239-251v.

56 AHN. Nobleza, Frías, C.118, D.2. 
JOSÉ MARÍA MONSALVO ANTÓN

RELACIONES ENTRE NOBLEZA Y MONARQUÍA EN EL SIGLO XV: FACCIONALISMO Y ACCIÓN POLÍTICA DE LOS ÁLVAREZ DE TOLEDO (CASA DE ALBA)

Algunos de los seguros se confunden con las cartas de amistad e confederación. Así ocurre con la de 6 de junio de 1464 en que el rey y su esposa aseguraban al conde y le incluían en cualquier confederación que hicieran ${ }^{57}$. Hubo otras cartas de seguro en aquellos años. Como la de finales de 1464, cuando el conde y otros firmaron para que saliera de la corte Beltrán de la Cueva ${ }^{58}$. O la de noviembre de 1467, cuando aparece con Carrillo y Pacheco firmando el seguro para que Isabel pudiese acudir a Arévalo libremente ${ }^{59}$.

¿Que contenían las «alianças y amistanças y confederaciones y contratos y pactos» ${ }^{60}$ ? Variaba un poco dependiendo de la modalidad. En el caso de las cartas de seguro el contenido es evidente. Aparte de ello, los acuerdos solían acabar con la solemnidad del pleito $e$ homenaje, como correspondía a nobles ${ }^{61}$. En las confederaciones entre muchos o pocos integrantes, se hallan siempre todos o algunos de estos tres compromisos que el lenguaje de los pactos muestra una y otra vez: la formalización de la alianza implicaba el servicio -siempre había un rey al que servir-, ser leales a la causa política o dinástica correspondiente - la que fuera en cada caso- y actuar solidariamente con los otros firmantes; implicaba dar ayuda, un concepto que entronca con los marcos culturales feudovasalláticos -auxilium - y que resultaba menos inconcreto de lo que parece, ya que casi siempre era sinónimo de una contribución materializada en contingentes de tropas; y finalmente, aunque es un argumento que podía quedar implícito, el pacto suponía la anulación o derogación de los anteriores, salvo que se indicara lo contrario.

Son muchas las alianzas donde se ven expuestos estos compromisos. En la carta del 13 de septiembre de 1441 aparecen los tres ${ }^{62}$. Otro ejemplo donde se aprecian perfectamente todos los elementos es el pacto entre el príncipe Enrique, Juan Pacheco, el almirante, el conde de Alba y su tío don Gutierre, que se rubrica solemnemente en Alba con la presencia de los cuatro últimos el 21 de junio de $1443^{63}$. O la confederación firmada el 25 de agosto de 1444 entre Luna, el conde de Alba y el almirante don Fadrique ${ }^{64}$.

A propósito de estos pactos del reinado de Juan II es preciso hacer alguna consideración sobre el papel del rey. Aunque este participaba en las alianzas, nunca era igual a los demás, dada la específica posición que se otorgaba a la dignidad real. Esto quiere

57 Decía Enrique IV «e que non faré trato nin amistad nin confederación con ninguna persona de mis reynos sin lo fazer saber a uos el dicho conde, para que seades en las tales confederaciones e amistades que yo fiziere», Documentos escogidos, pp. 5-6; PaZ y Melia, Ilustraciones, doc.13, pp. 71-72.

58 Memorias Enrique IV. Colección Diplomática, doc. 103.

59 DCasaAlba-Ávila, doc. 56; y Documentos escogidos, 8-9.

60 Estas diferentes formas de llamar los acuerdos en 10-X-1439, RAH, SyC, M-9, fol. 276v.

61 «Prometemos por nuestra fe e facemos pleito omenage, uno e dos e tres veces como caualleros y omes fijosdalgo, segund fuero e costumbre de Espańa», según la alianza de 15 de julio de 1465 (RAH, SyC, $\mathrm{K}-37$, fol. 30-30v), pero es fórmula muy habitual en muchos pactos.

62 Incluyendo la derogación de compromisos anteriores, que era una cláusula muchas veces implícita. Era una carta de seguro entre la reina dońa María, Juan de Navarra y otros muchos nobles, entre ellos el conde de Alba, que firmaban con Álvaro de Luna, comprometiéndose a no ir contra los respectivos adversarios. Se decía al final: «non enbargante otros qualesquier juramentos y votos y pleitos y omenajes y prometimientos y confederaciones y otros qualesquier contractos fechos entre nos los dichos reyna y príncipe y rey de Navarra y infante... o por nos los dichos condestable y arçobispo con vos los sobredichos", RAH, SyC, M-9, fol. 250v.

63 DCasaAlba-Salamanca, doc. 30.

64 Doc.Álvaro de Luna, doc 101. 
JOSÉ MARÍA MONSALVO ANTÓN

RELACIONES ENTRE NOBLEZA Y MONARQUÍA EN EL SIGLO XV: FACCIONALISMO Y ACCIÓN POLÍTICA DE LOS ÁLVAREZ DE TOLEDO (CASA DE ALBA)

decir que el rey se singularizaba cuando firmaba un acuerdo: él, por una parte; por otra, los demás. Un monarca podía estar en bandos y parcialidades con los nobles, pero no era uno más de ellos en términos de significado político, ni protocolarios, diplomáticos y ceremoniales.

También se manifestaba la especificidad regia en otras formalidades. Como, por ejemplo, el hecho de requerirse, o ser habitual al menos, la licencia real para efectuar determinados pactos ${ }^{65}$. El rey avalaba así los acuerdos, pues de hecho se incluían o insertaban en las propias cartas de pacto o seguro. Pero con las licencias el rey podía ejercer un cierto control sobre las alianzas internobiliarias ${ }^{66}$. Por lo que afecta a aquellas en las que estuvo concernido Fernando Álvarez de Toledo cabe mencionar la licencia otorgada por Juan II en 10 de octubre de 1439 para pacificar el reino, o la de 10 de septiembre de 1441 tras el apartamiento del poder del condestable ${ }^{67}$.

Pero, sobre todo, el monarca empleaba la capacidad de revocar con una autoridad que nadie más tenía, en términos formales, unos pactos y afianzar otros. Fijémonos, por ejemplo, en la citada licencia dada el 10 de octubre de 1439 para firmar una confederación de paz entre Luna y sus enemigos. Se decía que las otras confederaciones y ligas que pudiera haber con anterioridad quedaban revocadas: «yo los abrogo y derogo y alço y quito y amuevo y caso y yrrito y anulo de la dicha mi cierta ciencia y propio motu y poderío real absoluto y dispenso con ello y con cada cosa y parte dello.... ${ }^{68}$. Eso indicaba Juan II. Bien es cierto que en los pactos entre nobles, pactos de tipo más restringido y particular, se establecía también que la nueva alianza suprimía las anteriores. Pero, en el caso de las anulaciones sostenidas por el rey, la fórmula del poderio real absoluto suponía situar el nuevo acuerdo en un espacio político único, reforzado por el poder regio en términos formales. Aparte de los de $1439^{69}$, vemos en los documentos concernientes a los Alba que la fórmula del poderio real absoluto aparece en varias ocasiones: en 1440, cuando el rey aprobaba las seguridades dadas a Álvaro de Luna, el conde de Alba y su tío ${ }^{70}$, o en dos cartas de septiembre de 1441 cuando Juan II recurría a la fórmula del poderío absoluto, añadiendo "como rey y señor non reconosciente superior en lo temporal», para exigir a

65 No en pequeñas alianzas, pero sí cuando se buscaban grandes acuerdos de pacificación. La licencia era importante porque afectaba a una capacidad exclusiva del monarca. Se trataba de la facultad para suprimir ordenamientos y leyes existentes. Pero a la vez sobrevolaba la prohibición de hacer confederaciones. En las Cortes de Guadalajara de 1390 se había impuesto una severa prohibición a los nobles de hacer ayuntamientos e ligas, Cortes de los antiguos reinos de León y de Castilla. Madrid: Real Academia de la Historia, 1863, t. II, p. 426.

66 Lo señala Carrasco Manchado, «Léxico político en el Seguro de Tordesillas», p. 103.

67 RAH, SyC, M-9, fols. 276v-277v y 239-247v.

68 RAH, SyC, M-9, fol. 277r. Son los acuerdos de Castronuño entre Álvaro de Luna y rivales. La misma idea se repite el 15 de octubre, al dar licencia Juan II para que se firmase un seguro protegiendo bienes y hacienda de Álvaro de Luna. También se apelaba al poderío real absoluto: Juan II refrendaba con ella el pacto o pactos en ese momento firmados y la volvía a utilizar en la misma carta para anular cualquier acuerdo contrario a las seguridades e el contracto o contractos, Doc.Álvaro de Luna, doc. 63. El 29 de octubre Juan II volvía a utilizar la fórmula del poderío real absoluto para poner bajo su protección real a Álvaro de Luna, en una cédula dirigida a los miembros de la nobleza y el clero, entre ellos don Gutierre Álvarez de Toledo y su sobrino, Doc.Álvaro de Luna, doc. 66.

69 Vid. nota anterior.

70 Doc.Álvaro de Luna, doc. 79, de 1440. 
JOSÉ MARÍA MONSALVO ANTÓN

RELACIONES ENTRE NOBLEZA Y MONARQUÍA EN EL SIGLO XV: FACCIONALISMO Y ACCIÓN

POLÍTICA DE LOS ÁLVAREZ DE TOLEDO (CASA DE ALBA)

Juan de Navarra y sus partidarios y al entonces derrotado condestable que firmasen seguridades $^{71}$. Son solo algunos ejemplos del recurso político que se desprendía de la fórmula y que permitía hacer y deshacer al rey los pactos con una solemnidad única. Otras referencias al poderío real absoluto empleado para revocar pactos anteriores, anular mercedes y concederlas de nuevo las encontramos en documentos de $1445^{72}$ y $1448^{73}$.

En las numerosas confederaciones y cartas de amistança en que participó el conde de Alba durante el reinado de Enrique IV, aparte de estas cuestiones sobre el papel del rey ${ }^{74}$, las otras condiciones de los pactos eran semejantes y aparecen las tres premisas esenciales: unión solidaria y leal de los firmantes, con voluntad de servicio al rey; ayuda; y prevalencia o preçedencia de la alianza nueva sobre otras. En la confederación de fecha incierta, quizá de 1464, entre Enrique IV y la reina Juana con Carrillo, Pacheco, el condestable Velasco, el obispo Mendoza y los condes de Plasencia, Alba, Ledesma, Benavente, Paredes y Miranda, se aprecia que la ayuda a que apelaba el acuerdo era de hombres y armas: «e nos ayudaremos con cada çien lanças pagadas por un mes a nuestras costas, e después con aquellas gentes que oviere menester e la ayuda pidiere pagándola él y esto dadas quantas vezes fuere menester ${ }^{75}$. En la alianza firmada en marzo de 1466 por Beltrán de la Cueva, el marqués de Santillana, su hermano Pedro González de Mendoza y el conde de Alba, aparte de la ayuda y la derogación de otros compromisos, se pone de manifiesto

71 Ya que cualquier pacto o acuerdo al que llegasen, con independencia del pasado, el propio monarca avalaría y daría por bueno, RAH, SyC, M-9, fols. 239-247 v.

72 Doc.Alvaro de Luna, doc. 104; y DCasaAlba-Salamanca, doc. 31.

73 AHN, Nobleza, Frías, C.659, D.25. En octubre de ese año Juan II hacía concesión de Barco de Ávila a Juan Pacheco. Era una de las villas confiscadas al conde de Alba, que llevaba unos meses apresado. Es interesante comprobar cómo Juan II utilizaba la fórmula del poderío real absoluto varias veces en la carta de merced. La usaba como justificación de la confiscación: como Pedro y Suero de Quiñones, Enrique Enríquez y los condes de Benavente habían ido "contra la corona real», recurrió al poder absoluto para confiscar las villas. Después Juan II usa la fórmula para anular la merced dada al conde de Alba: «de mi propio motuo e çierta çiençia e poderío real absoluto de que en esta parte quiero usar e uso reuoco la tal merçed e quiero que sea en sý ninguna e de ningún valor». Finalmente, la fórmula servía para derogar todas aquellas normas, costumbres, etc., que pudieran ir contra esa decisión del rey, «ca yo del dicho mi poderío real absoluto e çierta çiençia de que quiero usar e uso en esta parte quanto a esto lo abrogo e derogo e anulo e alço e quito».

74 Que no difieren de las indicadas a propósito del reinado anterior. Incluso la condición singular del rey se tuvo en cuenta cuando se firmaron pactos con el rey aragonés. Por ejemplo, en 1460 el rey Juan II de Aragón y Navarra se adhería al pacto con varios nobles castellanos: el almirante, el marqués de Santillana, el obispo de Calahorra, el conde de Alba y el conde de Paredes. En esa alianza - presumiblemente preparada para ir ampliando la parcialidad contra Juan Pacheco- el rey aragonés no figura como uno más de los firmantes, sino que se singulariza frente al grupo de nobles castellanos, PAZ y Melia, Ilustraciones, doc. 8, pp. 13-19. Asimismo, en la amplia confederación que Juan II de Aragón firmaba con eclesiásticos y nobles castellanos, entre ellos el conde de Alba, en 1464, el Trastámara figura como una parte del pacto por sí solo, y los demás firman la confederación individualmente, pero se presentaban como conjunto frente a aquel. El propio documento aclaraba esta especial condición de Juan por el hecho de ser rey. Él se veía obligado a explicar que su implicación se basaba en su castellanidad, no en su condición de rey, y en esta excusatio se evidencia el peso de la condición regia: «suplicándouos non como rey, queriendo imperar en los dichos regnos, mas como natural oriundo por recta línea de la estirpe e casa real de Castilla, e como vezino de los dichos regnos e señoríos»; los aristócratas castellanos se dirigen a Juan II de Aragón como aliado, pero reconociendo que la alianza la hacían "con vuestra muy alta e serenísima real persona», AHN. Nobleza, Osuna, C.445, D.3.

75 AGS, PTR, leg. 11, doc. 79; y leg. 7, doc. 110. La fecha sugerida de 1464 ofrece no pocas dudas. 
JOSÉ MARÍA MONSALVO ANTÓN

RELACIONES ENTRE NOBLEZA Y MONARQUÍA EN EL SIGLO XV: FACCIONALISMO Y ACCIÓN POLÍ́TICA DE LOS ÁlVAREZ DE TOLEDO (CASA DE ALBA)

la propiedad transitiva que les obligaba entre sí y con sus respectivos aliados: «e seremos amigos de amigos e enemigos de enemigos», se dice elocuentemente ${ }^{76}$. La reina Juana se adhería poco después al acuerdo ${ }^{77}$.

\section{Conclusión}

Fernando y García encabezaron el linaje Álvarez de Toledo-Casa de Alba en los conflictivos reinados de Juan II, Enrique IV y comienzo del de Isabel I. Fue uno más entre la veintena o treintena, aproximadamente, de linajes de primera fila que hicieron movimientos semejantes y con repercusiones parecidas en una esfera de influencia que alcanzaba el reino entero. Como sus primos los Álvarez de Toledo de Oropesa, o como varias ramas de los Mendoza, o los Pimentel, o los dos grandes linajes que llevaban el apellido Enríquez - los de Alba de Liste y la familia del almirantazgo-, o los Ponce de León, los Guzmán, los Sarmiento, los Sotomayor, los Fernández de Córdoba, los Velasco, La Cueva, las dos ramas de los Estúñiga -las de Béjar y Miranda del Castañar-, los Manrique, los Acuña, los linajes del apellido Osorio, los Sandoval, los Quiñones, o las ramas principales del apellido Ayala, o los Portocarrero, los Guevara, los Carrillo, los Suárez de Figueroa y algunos otros. Si hacemos el ejercicio sencillo de multiplicar por veinte o treinta el cuadro presentado aquí sobre los Álvarez de Toledo a propósito de las ligas, a propósito de los señoríos y a propósito de las áreas de influencia genuinas, en este caso las actuales provincias de Ávila y Salamanca -si se suman todos se dibuja una malla nobiliaria que cubre todo el reino-, percibimos con nitidez una Castilla política y territorial totalmente incomprensible sin el papel de los nobles y sus movimientos.

El poder regio y las ciudades serían los otros grandes sujetos políticos a considerar. Es importante conocer de qué resortes se sirvieron unos y otros. Las ligas y facciones, desde luego, han de ser priorizadas en el caso de la nobleza. Se ha dicho que el estado en el feudalismo se materializaba allí donde un poder autónomo era capaz de ejercer la coerción. Los señoríos, pero también la zonificación regional de la influencia nobiliaria y su incidencia en el propio mundo urbano realengo, la presión sobre la evolución de la monarquía, ¿acaso no reflejan esta naturaleza estatal?, ¿no eran los grandes estados señoriales del siglo xv la mejor evidencia de ello? ¿Y no eran fruto, en gran medida, de la acción política y las alianzas nobiliarias? No cabe sino reconocer que el faccionalismo fue el principal recurso político de los nobles para forzar a los reyes a ceder y conseguir que concedieran mercedes y señoríos a los grandes linajes, abriendo así la puerta a esa gran acumulación de poder e influencia que alcanzaron durante la monarquía trastámara.

76 RAH, SyC, M-9, fols. 404v-405; AHN, Nobleza, Osuna, C.1860, D.16; Morales MuñIz, «Las confederaciones nobiliarias», doc. 3 .

77 Aseguraba «que non faré confederaçión nin amistad con ninguna persona syn consentymiento espreso de todos vosotros. E sy lo feziere quiero e es mi voluntad que sienpre e en todo tienpo e logar esta confederaçión que fago con vosotros preçeda a todas las otras escripturas de amistades que fasta aquí aya fecho o feziere de aquí adelante... E seré amiga de vuestros amigos e enemiga de vuestros enemigos», 1466, s.f. AHN, Nobleza, Osuna, C.1860, D.15. 
JOSÉ MARÍA MONSALVO ANTÓN

RELACIONES ENTRE NOBLEZA Y MONARQUÍA EN EL SIGLO XV: FACCIONALISMO Y ACCIÓN POLÍTICA DE LOS ÁLVAREZ DE TOLEDO (CASA DE ALBA)

4 Anexo. Los Álvarez de Toledo y las parcialidades, 1430-1479

Rehacemos aquí, con algunas pequeñas modificaciones y ampliaciones, el cuadro incluido en El sistema político concejil. El ejemplo del señorío medieval de Alba de Tormes y su concejo de villa y tierra. Salamanca: Ediciones Universidad de Salamanca, 1988, pp. 43-51. Refs. y abreviaturas.- Crónica de Juan II. Crónicas de los Reyes de Castilla, ed. C. Rosell. Madrid: Rivadeneyra, 1877, reed. BAE, 1953, tomo II (vol. 68 de la col.) (=Crónicas BAE II. Juan II); Crónica de don Juan II de Castilla por Alvar García de Santa María (14201434), en Colección de documentos inéditos para la Historia de España. Madrid: s. n., 1891, tomo XCIX (1420-1427), pp. 79-465, tomo C (1428-1434), pp. 3-409 (=García de Santa María, Crónica de Juan II); Carrillo de Huete, Pedro. Crónica del Halconero de Juan II, ed. J. de Mata Carriazo. Madrid: Espasa-Calpe, 1946 (=Crónica del Halconero); Refundición de la Crónica del Halconero, atribuida a Lope de Barrientos, ed. J. de Mata Carriazo. Madrid: Espasa-Calpe, 1946 (=Refundición Crónica Halconero); Crónica de don Álvaro de Luna (atribuida a Gonzalo Chacón), ed. J. Mata Carriazo. Madrid: EspasaCalpe, 1940 (=Crónica Á. de Luna); Enríquez del Castillo, Diego. Crónica de don Enrique el cuarto. Crónicas de los Reyes de Castilla, ed. C. Rosell. Madrid: Rivadeneyra, 1878, reed. BAE, 1953, tomo III (vol. 70 de la col.) (=Enríquez del Castillo, Crónica Enrique IV); esta crónica cuenta con una edición crítica de Sánchez Martín, Aureliano. Crónica de Enrique IV de Diego Enríquez del Castillo, Valladolid: Universidad de Valladolid, 1994 (=Crónica, ed. Sánchez Martín); Palencia, Alfonso de. Crónica de Enrique IV, ed. A. Paz y Melia. Madrid: Tipografía de la Revista de Archivos, 1904-1908, reed. BAE, 1973-1975, 3 vols. (=Palencia, Crónica); Crónica de Enrique IV, atribuida a Galíndez de Carvajal, ed. J. Torres Fontes, Estudio sobre la "Crónica de Enrique IV» del Dr. Galindez de Carvajal. Murcia: Suc. de Nogués, 1946 (=Galíndez, Crónica Enrique IV); Crónica anónima de Enrique IV de Castilla, 1454-1474 (Crónica castellana). Tomo II, Crónica, ed. M. ${ }^{a}$ P. SánchezParra. Madrid: Ediciones de La Torre, 1991 (=Crónica castellana); Valera, Diego de. Memorial de diversas hazañas. Crónicas de los reyes de Castilla, ed. C. Rosell. Madrid: Rivadeneyra, 1878, reed. BAE, 1953, tomo III (vol. 70 de la col.) (=Valera, Memorial); PAZ y Melia, Antonio. El cronista Alonso de Palencia. Su vida y obras; sus Décadas y las crónicas contemporáneas; ilustraciones de las Décadas y notas varias. Madrid: The Hispanic Society of America, 1914, con apéndice documental (=Paz y Melia, Ilustraciones); Memorias de don Enrique IV de Castilla. II. Colección diplomática del mismo rey. Madrid: Establecimiento Tipográfico de Fortanet, 1913 (=Memorias Enrique IV); Pulgar, Hernando del. Crónica de los Reyes Católicos. Crónicas de los Reyes de Castilla, ed. C. Rosell. Madrid: Rivadeneyra, 1878, reed. BAE, 1953, tomo III (vol. 70 de la col.) (=Pulgar, Crónica Reyes Católicos); Bernáldez, Andrés. Historia de los Reyes Católicos. Crónicas de los Reyes de Castilla, ed. C. Rosell. Madrid: Rivadeneyra, 1878, reed. BAE, 1953, tomo III (vol. 70 de la col.) (=Bernáldez, Historia); Archivo Ducal de Alba (=ADA); RAH, Colección Salazar y Castro (=RAH, SyC); Archivo Histórico Nacional, sección Nobleza (=AHN, Nobleza); Archivo Municipal de Alba de Tormes (=AMAT); Documentos escogidos del Archivo de la Casa de Alba, ed. duquesa de Berwick y de Alba. Madrid: s. n., 1891 (=Documentos escogidos). También algunos documentos en Calderón Ortega, José Manuel. Álvaro de Luna (1419-1453). Colección diplomática. Madrid: Dykinson, 1999 (=Doc.Álvaro de Luna). La documentación referida a Salamanca y Ávila fue objeto de algunas ediciones: Salamanca en la documentación medieval de la Casa de Alba, ed. Á. Vaca y J. A. Bonilla. Salamanca: Caja de Ahorros y Monte de Piedad de Salamanca, 1989 (=DCasaAlba-Salamanca); Do- 
cumentación medieval abulense en el Archivo de la Casa de Alba, ed. J. M. Calderón Ortega. Ávila: Institución Gran Duque de Alba, 2000 (=DCasaAlba-Ávila), autor que incluye también alguna de esta documentación en El ducado de Alba. La evolución histórica, el gobierno y la hacienda de un estado señorial (siglos XIV-XVI). Madrid: Dykinson, 2005. Pero en estos casos más relacionados con las provincias de Salamanca y Ávila, salvo por algunas referencias añadidas, preferimos dejar aquí la signatura que ya pusimos en su momento del archivo original, tal como aparecía en nuestro estudio de 1988. Pese a que se hallan ahora ya editados, hemos mantenido la referencia de archivo ya que este nuevo cuadro cronológico quiere ser una revisión algo ampliada de aquel cuadro primitivo incluido en El sistema político concejil, pero sin restar información del mismo. Eso sí, los documentos del archivo de Alba ahora aparecen con la signatura ADA, Archivo de los Duques de Alba, denominación que se considera hoy día más precisa que la de ACA, Archivo de la Casa de Alba, que empleamos entonces.

\begin{tabular}{|c|c|c|}
\hline $\begin{array}{l}\text { SitUACIÓN GENERAL DE LA NOBLEZA } \\
\text { EN EL REINO: LIGAS, FACCIONES Y } \\
\text { ENFRENTAMIENTOS }\end{array}$ & ACtuaciones de los miembros de la CASA & OfICIOS, RENTAS, SEÑORÍOS \\
\hline $\begin{array}{l}\text { - Protagonismo en Castilla de los infantes } \\
\text { de Aragón, Enrique y Juan (este, desde 1425, } \\
\text { rey de Navarra). } \\
\text { Se forma frente a ellos una gran coalición } \\
\text { nobiliaria que, con altibajos, aparece liderada } \\
\text { por Álvaro de Luna, que goza de la confianza } \\
\text { de Juan II. Los infantes de Aragón y Álvaro } \\
\text { de Luna desde } 1425 \text { y } 1426 \text { lideran sendas } \\
\text { facciones nobiliarias. } \\
\text { - Desde } 1428 \text { Álvaro de Luna consigue } \\
\text { importantes apoyos: el almirante Alfonso } \\
\text { Enríquez, el adelantado Pedro Manrique, el } \\
\text { conde de Benavente, el conde de Castańeda } \\
\text { y Pedro Fernández de Velasco. }\end{array}$ & $\begin{array}{l}\text { - Desde los ańos veinte Gutierre Álvarez de To- } \\
\text { ledo (obispo de Palencia, oidor de la Audiencia, } \\
\text { miembro del Consejo Real) y su sobrino Fernando } \\
\text { Álvarez de Toledo, seńor de Valdecorneja, habían } \\
\text { apoyado a Juan II y Álvaro de Luna. También su } \\
\text { primo Garci Álvarez de Toledo, señor de Oropesa. } \\
\text { En } 1425 \text { Fernando Álvarez representa al estado de } \\
\text { los caballeros de Toledo, junto a otros muchos, } \\
\text { en la proclamación de Enrique como príncipe he- } \\
\text { redero. Forma parte de los círculos de Álvaro de } \\
\text { Luna. (García de Santa María, Crónica de Juan II, t. } \\
\text { XCIX, pp. 358, 383). } \\
\text { En 1427 continúa con otros nobles en los círculos } \\
\text { regios (García de Santa María, Crónica de Juan II, } \\
\text { t. XCIX, pp. 446-447, 460; Crónica del Halconero, } \\
\text { pp. 12, 13, 18). }\end{array}$ & $\begin{array}{l}\text { - [Fernando Álvarez de Toledo } \\
\text { poseía ya el seńorío de Valdecor- } \\
\text { neja: concejos de villa y tierra de } \\
\text { Piedrahíta, Barco de Ávila, La } \\
\text { Horcajada, El Mirón (todos ellos } \\
\text { desde 1369) y la villa de Bohoyo, } \\
\text { adquirida en 1401]. }\end{array}$ \\
\hline \multicolumn{3}{|c|}{ 1429-1439. Primera victoria de Álvaro de Luna frente a los infantes de Aragón. Los Álvarez de Toledo, en el lado ganador. } \\
\hline $\begin{array}{l}\text { - 1429-1430. Guerra abierta entre el } \\
\text { grueso de la nobleza castellana, con Álvaro } \\
\text { de Luna y Juan II, contra los partidarios de } \\
\text { Juan, rey de Navarra, y Enrique, infantes de } \\
\text { Aragón. } \\
\text { Primera derrota de los infantes de Aragón. A } \\
\text { principios de } 1430 \text { se reparten sus posesio- } \\
\text { nes. Treguas de Majano. } \\
\text { - A partir de 1430, durante la estancia de } \\
\text { los infantes en Aragón tras su derrota caste- } \\
\text { llana, se fortalece el influjo sobre el monarca } \\
\text { de Álvaro de Luna. }\end{array}$ & $\begin{array}{l}\text { - Fernando Álvarez de Toledo forma parte de la } \\
\text { masiva coalición nobiliaria que derrota militarmen- } \\
\text { te a los infantes de Aragón. En } 1429 \text { era nombrado } \\
\text { capitán de la frontera en Requena, frente al reino de } \\
\text { Valencia (García de Santa María, Crónica de Juan } \\
\text { II, t. C, pp. 105-106, 115, 126; Refundición Cróni- } \\
\text { ca Halconero, p. 52). } \\
\text { - 1430-1431. Fernando Álvarez de Toledo com- } \\
\text { bate a los moros en Andalucía. (García de Santa } \\
\text { María, Crónica de Juan II, t. C, pp. 221, 243-244, } \\
\text { 272, 283, 285, 290, 313; Crónica del Halconero, } \\
\text { pp. 93, 95, 101; Refundición Crónica Halconero, } \\
\text { pp. 117, 120). }\end{array}$ & $\begin{array}{l}\text { - 1429. Gutierre de Toledo } \\
\text { obtiene Alba (ADA, c.304.22; } \\
\text { c.143.15). En diciembre Juan II } \\
\text { le concede la villa, hasta entonces } \\
\text { de Juan de Navarra (DCasaAlba- } \\
\text { Salamanca, doc. 6; Crónica del } \\
\text { Halconero, p. 52). } \\
\text { En marzo de } 1430 \text { es recibido } \\
\text { como señor de Alba (AMAT, } \\
\text { LAC, 1430, fol. 11). }\end{array}$ \\
\hline
\end{tabular}


JOSÉ MARÍA MONSALVO ANTÓN

- Los infantes van recuperando influencia y aliados en Castilla. Algunos movimientos de nobles (liderados por los jefes de linaje de los Mendoza, Velasco y, más tímidamente y al principio, el adelantado Pedro Manrique, el almirante Fadrique Enríquez y Rodrigo Alfonso Pimentel comienzan en 1432 a desconfiar de Luna. En 1432 se encarceló durante un tiempo a Pedro Velasco, conde de Haro, al obispo don Gutierre y a su sobrino Fernando Álvarez de Toledo. Ínigo López de Mendoza se alinea con ellos.

- No llega a fraguar una gran liga nobiliaria hasta varios años después, consumándose la ruptura de esta parcialidad de nobles con Álvaro de Luna hacia 1437. Ese año Pedro Manrique es hecho prisionero por orden de Álvaro de Luna, el almirante don Fadrique es perseguido y la liga antilunista empieza a organizarse.

- 1438. Juan II da licencia para intentar confederar a los nobles enfrentados y pacificar el reino. Intentos de solución con el otorgamiento de perdón regio a don Fadrique y Pedro Manrique.
- 1432. Fernando Álvarez de Toledo pasa un breve - 1430. Su sobrino, Fernando período en la cárcel (febrero-septiembre) por una Álvarez de Toledo, recibe Salvatiesupuesta rivalidad hacia Álvaro de Luna (varios no- rra de Tormes, que era antes del bles se opusieron ese ańo a Luna). Se le acusaba de infante Enrique de Aragón (García conspirar y tener fablas con don Juan de Navarra y de Santa María, Crónica de Juan los suyos (García de Santa María, Crónica de Juan II, t. C, p. 180; Crónica del HalII, t. C, pp. 335, 337-338; Crónica del Halconero, conero, p. 52; Refundición Crónica pp. 122-125, 137, 138; Refundición Crónica Halco- Halconero, p. 89). nero, pp. 129, 130, 138). tío mantienen su relación de lealtad al rey (García a Fernando Álvarez de Toledo de Santa María, Crónica de Juan II, t. C, p. 363; (RAH, SyC, M-63, fol. 63r-v).

Crónicas BAE II. Juan II, II, pp. 504-511; Crónica • Confirmación de los señoríos del Halconero, pp. 137-138).

- Fernando Alvarez de Toledo aparece a partir de rra de Tormes, 1434, 1437 1433- 1434 actuando como capitán mayor en la 1439 (ADA, c.169.6, c.302.22; frontera de Jaén, donde fue enviado por Juan II, c.143.15; c.256.34).

contribuyendo con 500 lanzas. En la guerra de • 27-11-1438. Fernando Álvarez Granada obtiene fama combatiendo con heroísmo de Toledo, miembro del Consejo durante los años 1434-1436 (ADA, c.2.10-12; Cró- real, recibe los oficios que tenía su nicas BAE II. Juan II, II, pp. 487-489, 494-499, suegro Pedro Carrillo, para cuando 512, 517, 520, 523, 527-528; Crónica del Halco- él falleciera. Los cargos y prebendas nero, pp. 165-167, 171-173, 200-209, 215, 227, eran: copero mayor, merino mayor 228; Refundición Crónica Halconero, pp. 156, 161, de Burgos, alguacil mayor de To163, 176, 178, 201; Crónica Á. de Luna, p. 142). ledo, con sus raciones; alcaldía de - 1437-1438. Fernando Álvarez de Toledo y su tío las sacas de Cuenca, con su quitadon Gutierre, cuando se forma la parcialidad con- ción; tierra-soldada de 45 lanzas; traria a Álvaro de Luna, continúan alineados con tercias de Cubas, Grińón y Vallecas este.

SyC, M-5, fol. 281v).

1439-1444. Parcialidades y hegemonía transitoria de los infantes de Aragón.

- 1439. Formación de la gran liga contra Álvaro de Luna, liderada por Juan de Navarra, infante de Aragón, desde principios de ese ańo. Guerra entre las dos facciones. Juan II apoya a Luna.

Los nobles titulados integrantes de la coalición antilunista eran numerosos: infante de Aragón don Enrique, hermano de Juan de Navarra; Fadrique Enríquez, almirante de Castilla; Enrique Enríquez, su hermano; Pedro Manrique, adelantado mayor; Juan Fernández Manrique, conde de Castañeda; Pedro Fernández de Velasco, conde de Haro; Pedro de Estúniga, conde de Ledesma; Rodrigo Alonso Pimentel, conde de Benavente; Juan de Acuña, conde de Valencia de don Juan; Î́nigo López de Mendoza, señor de Hita y Buitrago; Pedro de Quińones, merino mayor de Asturias; Suero, su hermano; Diego Gómez de Sandoval, conde de Castro.
- Fernando Álvarez de Toledo es de los pocos no- • 1439. Gutierre de Toledo, sebles que se mantiene del lado de Álvaro de Luna. La ñor de Alba, es elevado a la sede posibilidad de que los infantes de Aragón recupera- arzobispal de Sevilla, apoyado por sen las posesiones perdidas en 1430, entre ellas Alba Álvaro de Luna (en 1442 ocupará y Salvatierra, explica en buena medida el apoyo. la sede toledana).

Actúa en nombre de Luna y Juan II en Toledo con - 30-3-1439. Confirmación de 200 o 300 hombres (Crónicas BAE II. Juan II, II, Juan II a don Gutierre del señorío pp. 549, 550, 552; Crónica del Halconero, p. 279). de Alba (ADA, c.169.6).

- Junio 1439. Gutierre de Toledo, presente en el - 1439. Gutierre de Toledo trasjuramento del Seguro de Tordesillas para intentar pasa el seńorío de Alba de Tormes solucionar el conflicto entre las parcialidades en- a su sobrino Fernando Álvarez de frentadas (AHN, Nobleza, Frías, C.5, D.5).

- 1439. Fernando Álvarez de Toledo fortifica y defiende la villa de Alba de Tormes frente a los infantes de Aragón y sus aliados. Pretensión de Juan de $\mathrm{Na}$ varra de recuperar Alba, antigua posesión señorial suya y de los infantes (Crónicas BAE II. Juan II, II, pp. 556, 558; Crónica del Halconero, p. 292).
Toledo, a quien el rey concede el título de conde a finales de ese año, concretamente el día de Navidad según la Crónica del Halconero. Era entonces el principal y casi único apoyo relevante de Juan II y Álvaro de Luna ante la liga del infante Juan de Navarra (Crónicas BAE II. Juan II, II, p. 558; Crónica del Halconero, p. 302). 
- Intento fallido de solución de las disputas en el verano de 1439 en Tordesillas y en un pacto entre partidarios de Álvaro de Luna y de Juan de Navarra de 15 octubre en Castronuño.

- Finales de 1440. Doña María, reina de Castilla, hermana de los infantes de Aragón Juan y Enrique, se une a ellos.

Se unen también a ellos el príncipe Enrique y su "privado" Juan Pacheco.

- Los apoyos del Condestable en esos años, en que cuenta con el aval de Juan II, eran muy escasos: además de don Gutierre Álvarez de Toledo y su sobrino Fernando Álvarez de Toledo, Pedro Carrillo, el maestre de Alcántara Gutierre de Sotomayor, Pedro Álvarez Osorio, Alfonso de Vivero, contador mayor, y Lope de Barrientos, obispo de Segovia.

- Principios de 1441. Se completa el desafío a Álvaro de Luna por parte de la coalición nobiliaria liderada por los infantes de Aragón.

- Junio 1441. Victoria del bando de Juan de Navarra en Medina. Los antilunistas «se apoderan del rey", reteniéndole en palacio mientras se expulsaba de la corte a los partidarios del condestable. Destierro de Álvaro de Luna, que se ha de refugiar en su villa de Escalona.

- 3/9-7-1441. "Sentencia de Medina» contra Luna. Bajo la presión de la reciente victoria en Medina de Juan de Navarra y los suyos, redactan la Sentencia la reina dońa María, el príncipe don Enrique, el almirante don Fadrique y el conde de Alba.
- 15/20-10-1439. Presente el conde de Alba en el acuerdo de Castronuño y otras tentativas en otońo de ese año que intentaron solucionar los conflictos entre los infantes de Aragón y Luna (RAH, SyC, M-9, fols. 276r-279v; Doc.Álvaro de Luna, docs. $63,64,66)$.

- 1440. Mientras los infantes de Aragón ocupan algunas villas, Fernando Álvarez de Toledo resiste en Alba. Ese año es, junto con su tío don Gutierre, el principal baluarte de Luna y de las tropas de Juan II.

A principios de marzo el rey encargó al conde de Alba tomar Ávila. Estancia de Juan II en Valdecorneja en Pascua, con el conde de Alba. En la primavera de 1440 Fernando y su tío don Gutierre firman una seguridad en Escalona y Alba con Álvaro de Luna (Doc.Álvaro de Luna, docs. 76 79; Crónicas BAE II. Juan II, II, p. 563; Crónica del Halconero, pp. 303, 307, 311, 313-315, 333-335).

- Enero-marzo de 1441. Los partidarios de los infantes de Aragón intentan apartar al conde de Alba y su tío de la corte y del Consejo. En plena guerra contra los infantes de Aragón, María de Aragón y el grueso de la nobleza castellana, que constituían un gran bloque de enemigos, Juan II encomienda a Fernando Álvarez de Toledo, leal a su causa, la defensa de las ciudades de Salamanca, Ciudad Rodrigo y Ávila. Se encarga de la guarda de Salamanca y Juan II le da facultad para ocupar el alcázar de la ciudad (ADA, c. 2.33 , c. 2.34, c. 2.36 , c. 2.37 , c. 2.38 , c.2.39, c.2.40, c.2.41, c.2.43; DCasaAlbaSalamanca, docs. 12-18, 21, 22; DCasaAlba-Ávila, doc. 16; Crónica del Halconero, p. 374).

- Febrero 1441. Fernando Álvarez de Toledo, confederado con Álvaro de Luna, responde al desafío de los infantes (ADA, c.62.15; Doc.Álvaro de Luna, doc.89).

- Primavera 1441. El conde de Alba en abril entra en Ávila con 500 hombres a caballo y 1.500 de a pie - según Carrillo de Huete-, venciendo a Juan de Navarra. El conde vence también en mayo en Medina del Campo. En junio continúa la presión militar de los partidarios del rey de Navarra sobre esta villa. (Crónicas BAE II. Juan II, II, pp. 579580, 583-584; Crónica del Halconero, pp. 392, 396, 399, 404, 411-416, ADA, c.2.46, c.2.47).

- Fines de junio de 1441. Derrota lunista. Sus enemigos controlan Medina y custodian a Juan II. Confederación el 30 de junio del conde de Alba, su tío don Gutierre, la reina dońa María y Lope de Barrientos (DCasaAlba-Salamanca, doc. 25; Crónica del Halconero, pp. 417-421).
- Enero, 1440. Juan de Navarra renuncia a recuperar Alba de Tormes (ADA c.198, 24).

- 2-4-1440. Juan II hace merced a Fernando Álvarez de Toledo del oficio de camarero mayor del príncipe don Enrique (ADA, c. 156.20; DCasaAlba-Ávila, docs. 12, 13; Crónica del Halconero, p. 336).

- 29-2-1441. Juan II hace merced al conde de Alba, aunque todavía no tuvo efecto, del oficio de alguacil mayor de Ávila (ADA, c. 156.21; DCasaAlba-Ávila, doc. 17). 
JOSÉ MARÍA MONSALVO ANTÓN

RELACIONES ENTRE NOBLEZA Y MONARQUÍA EN EL SIGLO XV: FACCIONALISMO Y ACCIÓN

POLÍTICA DE LOS ÁLVAREZ DE TOLEDO (CASA DE ALBA) \begin{tabular}{|l|l|}
\hline Se prescribe el apartamiento del gobierno de & • 3/7-7-1441. El conde de Alba participa en la \\
Álvaro de Luna, que no pueda confederar- & Sentencia arbitral de Medina. El conde fue de Me- \\
se con nadie y que esté confinado durante & dina a Alba. Aquí, el día 6, recibió la Sentencia que \\
seis ańos en alguna de sus villas, salvo las & él y otros habían redactado unos días antes. El 7 la \\
que debía entregar en ese tiempo (Escalona, & firmó. Se certifican estos viajes y estancia a petición \\
Maqueda, Montalbán y otras). Se prescribe & suya (ADA, c.2.49, c.2.50). \\
-y se cumple parcialmente- la supresión de & • El conde de Alba deja libre en 7-7-1441 el castillo \\
mercedes concedidas desde 1438 y el control & de Salamanca (ADA, c.2.50). \\
del Consejo Real por los vencedores. & -3/9-7-1441. Habiendo sido hasta entonces lunista, \\
Juan de Navarra y el almirante Fadrique En- & el conde de Alba aparece protagonizando la Senten- \\
ríquez, hegemonizan hacia 1442, pero con & cia. En la queja de Álvaro de Luna de 22-7-1441 el \\
rivalidad entre ellos, la actividad del bloque & condestable entendía que su enemigo capital Juan de \\
triunfador. & Navarra había conseguido su propósito; y que el con- \\
- 1442-1443. Preeminencia de los infantes & de de Alba, por themor... e por non osar desplazarles, \\
de Aragón, que controlan la actividad de Juan & se había visto presionado por la reina, el príncipe y el \\
II, sobre todo tras la toma del poder de Rá- & almirante a firmar la Sentencia de Medina.
\end{tabular} maga (hoy Rágama) en julio de 1443, cuando Juan II quedaba en menos de los infantes. Los infantes y Fadrique Enríquez apartan del poder, expulsándolos del Consejo, a los partidarios de Álvaro de Luna.

- Se inicia la oposición a los infantes, que controlaban la acción de Juan II. Como nuevas figuras que canalizan el malestar aparecen Juan Pacheco y el propio príncipe Enrique de Castilla. En los últimos meses de 1443 buscan el regreso al poder de Álvaro de Luna, para reforzar una gran coalición contra los infantes de Aragón.

- 1444. Se forma, con el beneplácito de Juan II, un sector contrario a los infantes. Iniciado por los Alba y Lope de Barrientos, se fueron uniendo otros: el príncipe y Juan Pacheco; Álvaro de Luna; Ínigo López de Mendoza, el conde de Castańeda; el conde de Haro; el conde de Plasencia. Consiguen tener un gran ejército de varios miles de hombres (según las crónicas del reinado) que ponen al servicio Juan II. Los infantes preparan un gran ejército castellano-aragonés.

- 1445. Las tropas de los infantes avanzan por Castilla. Cuentan con el almirante don Fadrique, con el conde de Benavente, con Pedro de Quiñones, con Diego Gómez de Sandoval, conde de Castro. Apoyan, además, el linaje de la Cerda y los Ponce de León.
Fernando Álvarez de Toledo señor de Alba y Valdecorneja, mantiene sus posesiones señoriales de 1430 y las concesiones desde 1438 pese a la derrota en 1441 de Álvaro de Luna. Sus movimientos y los pactos de la Sentencia de Medina así lo permiten (DCasaAlba-Salamanca, doc. 28; RAH, SyC, M-9, fols. 239r-251v). docs. 26, 27; Doc.Álvaro de Luna, doc. 91).

- 10/13-9-1441. El conde de Alba y su tío don Gutierre participan en el seguro que se otorga por parte de los infantes y muchos nobles a Álvaro de Luna (RAH, SyC, M-9, fols. 239r-251v).

- 21-6-1443. Ante el auge de Juan de Navarra, confederación entre el almirante Fadrique Enríquez (que poco después se implicaría, en contra de este pacto, en el golpe de Rámaga), Juan Pacheco, Gutierre de Toledo y su sobrino Fernando Álvarez de Toledo, conde de Alba. El propósito era reforzar al liderazgo del príncipe don Enrique (ADA, c.25.10; DCasaAlba-Salamanca, doc. 30).

-1443-1444. Después del golpe de "Rámaga", Gutierre de Toledo, el conde de Alba y Lope de Barrientos constituyen el núcleo que inicia la adhesión de otros nobles contra el infante don Juan de Navarra. Bajo el liderazgo del príncipe Enrique, unido al renacido por entonces Álvaro de Luna, inician desde Ávila movimientos de tropas. El conde de Alba aporta trescientos hombres a caballo (Crónicas BAE II. Juan II, II, pp. 619-621).

- 1444. Fernando Álvarez de Toledo, conde de Alba, participa activamente en las operaciones militares en pro de Juan II, del príncipe don Enrique y de Álvaro de Luna, según carta regia de julio de ese ańo. El 25 de agosto de 1444 firmaban contrato de alianza Álvaro de Luna y Fernando Álvarez de Toledo. El conde de Alba lidera en tierras burgalesas y otras la victoria sobre las tropas de Juan de Navarra.
- 1442. Gutierre de Toledo consigue el arzobispado de Toledo. Pero tarda un tiempo en hacerse cargo de la diócesis (Crónicas BAE II. Juan II, II, pp. 610, 614-615). .

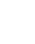

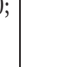


JOSÉ MARÍA MONSALVO ANTÓN

RELACIONES ENTRE NOBLEZA Y MONARQUÍA EN EL SIGLO XV: FACCIONALISMO Y ACCIÓN POLÍTICA DE LOS ÁlVAREZ DE TOLEDO (CASA DE ALBA)

\begin{tabular}{|c|c|c|}
\hline & $\begin{array}{l}\text { Interviene en la toma de Roa y otras acciones de } \\
\text { guerra. Juan II ordena a Ávila, Salamanca y Ciudad } \\
\text { Rodrigo ponerse a las órdenes del conde de Alba. El } \\
\text { conde es protagonista en la coalición militar contra } \\
\text { Juan de Navarra. Presente en las capitulaciones de } \\
\text { 28-10-1444 de tregua con el rey de Navarra, en re- } \\
\text { presentación de Juan II (ADA, c.2.53, c.2.55; Doc. } \\
\text { Álvaro de Luna, doc. 101; DCasaAlba-Ávila, doc. } \\
\text { 21; AHN. Nobleza, Frías, C.118, D.2; Crónicas } \\
\text { BAE II. Juan II, II, p. 622). }\end{array}$ & $\begin{array}{l}\text { - 5-4-1444. El príncipe don } \\
\text { Enrique nombra al conde de Alba } \\
\text { su camarero mayor (DCasaAlba- } \\
\text { Ávila, doc. 20). }\end{array}$ \\
\hline \multicolumn{3}{|c|}{ 1445-1447. Hegemonía compartida de Álvaro de Luna y príncipe don Enrique. El conde, en el bando de los vencedores. } \\
\hline $\begin{array}{l}\text { - } 19 \text { de mayo de } 1445 \text {. Victoria de Olme- } \\
\text { do. Juan II, el príncipe Enrique y Álvaro de } \\
\text { Luna, con los nobles partidarios, vencen a los } \\
\text { infantes de Aragón definitivamente. } \\
\text { - } 1445 \text {. Los vencedores en la batalla de } \\
\text { Olmedo son recompensados, sobre todo } \\
\text { con mercedes de los vencidos: Ínígo López } \\
\text { de Mendoza es hecho marqués de Santillana; } \\
\text { Juan Pacheco, marqués de Villena, seńo- } \\
\text { río de Medellín; su hermano Pedro Girón, } \\
\text { maestre de Calatrava; Álvaro de Luna obtie- } \\
\text { ne Alburquerque y maestrazgo de Santiago, } \\
\text { entre otros. } \\
\text { - } \quad \text { 1445-1447. Comienzan tensiones laten- } \\
\text { tes en el bando de los vencedores de Olmedo } \\
\text { entre dos facciones, que intentan dirigir los } \\
\text { movimientos de la corte: la de Álvaro de } \\
\text { Luna y la del príncipe don Enrique, este úl- } \\
\text { timo con su hombre fuerte Juan Pacheco, el } \\
\text { hermano de este Pedro Girón y el conde de } \\
\text { Castro, Diego Gómez de Sandoval, antiguo } \\
\text { hombre de los infantes y ahora puente su- } \\
\text { brepticio con los partidarios de estos, derro- } \\
\text { tados pero con influencia todavía entre los } \\
\text { nobles castellanos, sobre todo bajo el lideraz- } \\
\text { go del almirante Fadrique. Además de este, } \\
\text { el conde de Benavente Alfonso Pimentel, los } \\
\text { Estúñiga, los Quińones o los Tovar fueron } \\
\text { tomando partido contra Álvaro de Luna. }\end{array}$ & $\begin{array}{l}\text { - Mayo-junio de 1445. El conde de Alba es uno de } \\
\text { los participantes destacados en la victoria de Olme- } \\
\text { do contra los infantes de Aragón. Participa en los } \\
\text { seguros que Juan II otorga al príncipe y a Álvaro } \\
\text { de Luna en junio de } 1445 \text { (Crónicas BAE II. Juan } \\
\text { II, II, pp. 627-629; Crónica del Halconero, pp. 459- } \\
\text { 461, 463-464; RAH, SyC, K-36, fols. 148r-150v). } \\
\text {-1445-1446. Fernando Álvarez de Toledo, conde } \\
\text { de Alba, uno de los artífices de la victoria de Ol- } \\
\text { medo, situado en la parcialidad de Álvaro de Luna, } \\
\text { continúa en la órbita de este (Crónica Á. de Luna, } \\
\text { pp. 159, 168). } \\
\text { - Progresivo alejamiento del conde de Alba desde } \\
\text { 1446 -muerto su tío don Gutierre- del círculo del } \\
\text { príncipe Enrique. Juan II le había concedido ańos } \\
\text { atrás Quesada, en tierras de Úbeda, pero el príncipe } \\
\text { no se avino a que la poseyera. Tampoco estaba dis- } \\
\text { puesto el príncipe a que la villa de Miranda, que se } \\
\text { le había concedido al conde, fuera enajenada de la } \\
\text { corona. Es posible que estas contrariedades alejaran } \\
\text { al conde de la parcialidad de Pacheco-Enrique y del } \\
\text { propio Juan II. } \\
\text { El conde participaba en diciembre de } 1446 \text { con } \\
\text { otros nobles -Ínigo López de Mendoza, Pedro de } \\
\text { Estúńiga, Diego Gómez de Sandoval, Alfonso Pi- } \\
\text { mentel, entre otros- en la confederación firmada } \\
\text { por el conde de Haro, Pedro Fernández de Velasco } \\
\text { y por el almirante don Fadrique (PAstor BoDMER, } \\
\text { Isabel. Grandeza y tragedia de un valido: la muerte de } \\
\text { don Álvaro de Luna. II. Documentos. Madrid: Caja } \\
\text { de Madrid, 1992, pp. 198-199; Crónicas BAE II. } \\
\text { Juan II, II, pp. 642, 648). } \\
\text { - 1447. Entrada en la parcialidad encabezada } \\
\text { por don Fadrique, con cuya hija María Enríquez } \\
\text { enlazará el primogénito del conde de Alba, García } \\
\text { Álvarez de Toledo. Por las vicisitudes políticas los } \\
\text { esponsales se retrasaron considerablemente (ADA, } \\
\text { c.198.24). }\end{array}$ & $\begin{array}{l}\text { - Desde } 1445 \text { Fernando Álvarez } \\
\text { de Toledo recoge los frutos de su } \\
\text { alineamiento y victoria. } \\
\text { - Junio } 1445 \text {. Juan II le concede } \\
\text { los bienes confiscados a su con- } \\
\text { tador Fernán López de Saldaña, } \\
\text { que siguió a los infantes (ADA, } \\
\text { c.156.22; Doc.Álvaro de Luna, } \\
\text { doc 104; DCasaAlba-Salamanca, } \\
\text { doc. 31). } \\
\text { - 1446-1447. El conde, titular } \\
\text { oficial de Alba, tras la muerte de } \\
\text { su tío Gutierre en 1446, que le } \\
\text { había hecho heredero universal. } \\
\text { Hereda también Torrejón de Ve- } \\
\text { lasco (ADA, c.198.24). } \\
\text { - 20-1-1446. Obtiene Granadi- } \\
\text { lla, Abadía, Miranda del Castañar } \\
\text { (no se hizo efectivo) y Garganta la } \\
\text { Olla (ADA, c.198.24). } \\
\text { - 3-3-1447. Por trueque obtie- } \\
\text { ne Pasarón y Torremenga ADA, } \\
\text { c.198.24; GERBET, Marie-Clau- } \\
\text { de. La noblesse dans le royaume de } \\
\text { Castille. Paris: Publications de la } \\
\text { Sorbonne, 1979, p. 269). } \\
\text {-1447. Testamento de Fernan- } \\
\text { do Álvarez de Toledo (ADA, } \\
\text { c.143.15). } \\
\text { - Según datos de 1447 (Suárez, } \\
\text { Luis. «Un libro de asientos de } \\
\text { Juan II». Hispania, 1957, vol. 68, } \\
\text { p. 338) el conde de Alba percibía } \\
\text { anualmente procedente de rentas } \\
\text { regias casi un millón de marave- } \\
\text { díes -en lo salvado, juros, mante- } \\
\text { nimientos, quitación-, una de las } \\
\text { mayores del reino. }\end{array}$ \\
\hline
\end{tabular}


JOSÉ MARÍA MONSALVO ANTÓN

\begin{tabular}{|c|c|c|}
\hline \multicolumn{3}{|c|}{ 1448-1453. Hegemonía de Álvaro de Luna hasta su caída. Estancia en prisión del conde de Alba. } \\
\hline $\begin{array}{l}\text { - 11-5-1448. Golpe de Záfraga, auspiciado } \\
\text { por Alfonso de Fonseca y Juan Pacheco, con } \\
\text { el apoyo del príncipe, y Álvaro de Luna, con } \\
\text { el apoyo del rey, que aparcan antiguas renci- } \\
\text { llas. El pacto implicaba la prisión y persecu- } \\
\text { ción de algunos nobles ligados al almirante } \\
\text { don Fadrique y al rey Juan de Navarra: Pedro } \\
\text { y Suero de Quiñones, el conde de Alba, el } \\
\text { conde de Benavente y Enrique, el hermano } \\
\text { del almirante. Estos últimos escapan de la } \\
\text { prisión. }\end{array}$ & $\begin{array}{l}\text { - 11-5-1448. El conde de Alba, alineado con } \\
\text { el almirante Fadrique Enríquez (que fue su con- } \\
\text { suegro) y con Juan de Navarra, su gran enemigo } \\
\text { antaño. Varios son encarcelados por ir contra la } \\
\text { corona real. Este sector estaba enfrentado al bando } \\
\text { del príncipe don Enrique y al de Álvaro de Luna, } \\
\text { en ese momento unidos. Es apresado el conde de } \\
\text { Alba. Tras pasar por Roa, es trasladado a Segovia } \\
\text { (ADA, c.2.100, c.196.18; DCasaAlba-Ávila, doc. } \\
\text { 23; AHN, Nobleza, Frías, C.659, D.25; Crónicas } \\
\text { BAE II. Juan II, II, pp. 656-658; Crónica del Halco- } \\
\text { nero, pp. 499-500, 503; Crónica Á. de Luna, p. 213; } \\
\text { Palencia, Crónica, I, pp. 80-81). }\end{array}$ & $\begin{array}{l}\text { - } 18 \text { y 22-5-1448. Secuestro de } \\
\text { las villas del conde de Alba: las de } \\
\text { Valdecorneja, Alba, Salvatierra, } \\
\text { Granadilla, Miranda del Castañar } \\
\text { (en litigio), Pasarón, Garganta la } \\
\text { Olla, y los lugares de Villoria y } \\
\text { Babilafuente, amén de la fortaleza } \\
\text { de Villanueva de Cañedo. (ADA, } \\
\text { c.196.18, c.3.3, c.3.4, c.62.13; } \\
\text { DCasaAlba-Avila, docs. 24, 25; } \\
\text { DCasaAlba-Salamanca, docs. 34, } \\
\text { 35). }\end{array}$ \\
\hline $\begin{array}{l}\text { - 1448-1453. Período de hegemonía de Ál- } \\
\text { varo de Luna. Aumento de la rivalidad entre } \\
\text { Luna y el príncipe con Juan Pacheco. Estos } \\
\text { últimos aglutinan el descontento hacia Luna } \\
\text { de numerosos nobles, que desean la caída del } \\
\text { condestable: Pedro de Estúńiga, conde de } \\
\text { Plasencia; Pedro Fernández de Velasco, con- } \\
\text { de de Haro; Í́íigo López de Mendoza, mar- } \\
\text { qués de Santillana; Alonso Pimentel, conde } \\
\text { de Benavente. } \\
\text { Desde el verano de } 1449 \text { operaba una liga } \\
\text { nobiliaria con estos y otros integrantes. In- } \\
\text { tentos fallidos a lo largo de este ańo para } \\
\text { lograr la liberación de los prisioneros tras el } \\
\text { Pacto de Záfraga. En } 1450 \text { habían salido de } \\
\text { prisión los encarcelados en 1448, excepto el } \\
\text { conde de Alba. }\end{array}$ & $\begin{array}{l}\text { - 1448-1454. Prisión del conde de Alba, Fernan- } \\
\text { do Âlvarez de Toledo. El marqués de Santillana, } \\
\text { como si fuera su hermano, dedicará al conde de } \\
\text { Alba su poema consolatorio Bias contra Fortuna. } \\
\text { - 1448. García Álvarez de Toledo, primogénito del } \\
\text { conde, acude a Aragón a pedir ayuda del almirante, } \\
\text { refugiado alli. (Palencia, Crónica, I, p. 81-82). } \\
\text { 1450-1452. García Álvarez de Toledo actúa polí- } \\
\text { ticamente con los enemigos de Álvaro de Luna, y } \\
\text { también militarmente, en correrías diversas (con su } \\
\text { hermano Pedro), con el objeto de que su padre sal- } \\
\text { ga de prisión. Intentos numerosos de negociación } \\
\text { para que el conde de Alba saliera de la prisión. El } \\
\text { príncipe Enrique, el más interesado en mantener en } \\
\text { prisión al conde. Desde 1450, liberados los otros } \\
\text { presos de 1448, sólo el conde siguió encarcelado. } \\
\text { Intentos en 1451 de liberar al conde, que no acaban } \\
\text { de fraguar. (ADA, c.62.12, c.3,5-10, entre otros; } \\
\text { DCasaAlba-Ávila, docs. 26-32; Palencia, Crónica, } \\
\text { I, pp. 86-87). }\end{array}$ & $\begin{array}{l}\text { - 20-10-1448. Juan II concede } \\
\text { Barco de Ávila -una de las con- } \\
\text { fiscadas al conde- a Juan Pacheco, } \\
\text { marqués de Villena y mayordomo } \\
\text { mayor del príncipe don Enrique } \\
\text { (AHN, Nobleza, Frías, C.659, } \\
\text { D.25). } \\
\text { - 3-3-1451. Juan II y el príncipe } \\
\text { instan a García Álvarez de Toledo, } \\
\text { para que deje libres las villas confis- } \\
\text { cadas (DCasaAlba-Ávila, doc. 27; } \\
\text { PAsTor BoDmER, Grandeza y trage- } \\
\text { dia de un valido, pp. 299-300). } \\
\text { El príncipe ocupó alguna, según } \\
\text { documentación de Alba de 30-4- } \\
\text { 1454 (Documentación histórica del } \\
\text { AM de Alba de Tormes, ed. Monsal- } \\
\text { vo Antón. Salamanca: Diputación } \\
\text { de Salamanca, 1988, doc. 152). }\end{array}$ \\
\hline $\begin{array}{l}\text { - 1452. Máxima rivalidad entre Álvaro } \\
\text { de Luna y la amplia parcialidad de nobles } \\
\text { agrupados en torno al príncipe don Enrique: } \\
\text { Pacheco y linajes Enríquez, Pimentel, Men- } \\
\text { doza, Velasco, Estúńiga y otros. } \\
\text { - Junio de } 1453 \text {. Ejecución de Álvaro de } \\
\text { Luna }\end{array}$ & $\begin{array}{l}\text { - 1452. Don García, atrincherado en Piedrahíta. } \\
\text { Aliado de Pedro de Estúńiga, consigue apoyos mi- } \\
\text { litares de otros nobles antilunistas, como los Men- } \\
\text { doza, los Velasco y los Pimentel. Acercamiento al } \\
\text { príncipe Enrique (Crónicas BAE II. Juan II, II, p. } \\
\text { 676-677; Palencia, Crónica, I, p. 108-109) } \\
\text { - Pese a la muerte de Luna y los fuertes aliados de } \\
\text { García Álvarez de Toledo, entre ellos el príncipe, } \\
\text { Juan II se niega a liberar a Fernando Álvarez de To- } \\
\text { ledo (Crónicas BAE II. Juan II, II, p. 677). } \\
\text { - Julio-1453. Se abren expectativas de liberación. } \\
\text { Hasta entonces don Garć́a y su hermano don } \\
\text { Pedro se moverían con libertad por sus antiguos } \\
\text { seńoríos (ADA, c. 2.58-60, c.2.61-66; DCasaAlba- } \\
\text { Ávila, ed. Calderón, docs. 37-41) }\end{array}$ & $\begin{array}{l}\text { - 1451-1454. Negociaciones con } \\
\text { el príncipe sobre la tenencia de las } \\
\text { villas confiscadas. Don García in- } \\
\text { tenta que su padre salga de prisión } \\
\text { (CALDERón OrTEGA, El Ducado } \\
\text { de Alba, docs. 12-16; DCasaAlba- } \\
\text { Ávila, docs. 37-47; DCasaAlba- } \\
\text { Salamanca, docs. 34-37; PAsTor } \\
\text { BoDMER, Grandeza y tragedia de } \\
\text { un valido, pp. 357-358). } \\
\text { - 10-9-1454. El conde recupe- } \\
\text { ra sus bienes y seńoríos (ADA, } \\
\text { c.156.60, c. 126.26; CaLDERóN } \\
\text { OrTEGa, El Ducado de Alba, doc. } \\
\text { 17; DCasaAlba-Ávila, doc. 48; } \\
\text { DCasaAlba-Salamanca, doc. 38). }\end{array}$ \\
\hline
\end{tabular}


JOSÉ MARÍA MONSALVO ANTÓN

RELACIONES ENTRE NOBLEZA Y MONARQUÍA EN EL SIGLO XV: FACCIONALISMO Y ACCIÓN POLÍ́TICA DE LOS ÁlVAREZ DE TOLEDO (CASA DE ALBA)

\begin{tabular}{|c|c|c|}
\hline & $\begin{array}{l}\text { - El conde sale de prisión (ADA, c. 126.26; } \\
\text { DCasaAlba-Avila, doc. 48; DCasaAlba-Salamanca, } \\
\text { doc. 38; Enríquez del Castillo, Crónica Enrique IV, } \\
\text { p. 102; Crónica, ed. Sánchez Martín, pp. 136-137; } \\
\text { Crónica castellana, pp. 11-12; Palencia, Crónica, I, } \\
\text { p. 149-150). }\end{array}$ & \\
\hline \multicolumn{3}{|c|}{ 1454-1464. Movimientos nobiliarios y formación de nuevas ligas. El conde, del apoyo al rey al acercamiento a sus rivales. } \\
\hline $\begin{array}{l}\text { - 1454-1460. Enrique IV reina bajo la pri- } \\
\text { vanza del nuevo hombre fuerte Juan Pache- } \\
\text { co, marqués de Villena. Este mantiene lazos } \\
\text { estrechos con muchos nobles, con los que } \\
\text { llega a numerosos acuerdos. } \\
\text { Se va paulatinamente produciendo un des- } \\
\text { contento en otro sector de la nobleza, pero } \\
\text { sin llevar a conflictos abiertos. Alonso Carri- } \\
\text { llo, arzobispo de Toledo, el conde de Haro y } \\
\text { el almirante don Fadrique, encabezan estos } \\
\text { movimientos. } \\
\text { - En } 1459 \text { Alonso Carrillo y otros nobles } \\
\text { (el marqués de Santillana, el conde de Haro, } \\
\text { el conde de Paredes y otros) intentan reducir } \\
\text { la posición de influencia de Juan Pacheco en } \\
\text { el entorno de Enrique IV. }\end{array}$ & $\begin{array}{l}\text { - 1455. El conde de Alba participa en expedicio- } \\
\text { nes militares contra los musulmanes (Enríquez del } \\
\text { Castillo, Crónica Enrique IV, p. 106; Crónica, ed. } \\
\text { Sánchez Martín, pp. 150-151; Palencia, Crónica, I, } \\
\text { pp. 174-176; Crónica castellana, pp. 39, 43). } \\
\text { - 1456. Carta de seguro y amistad de Enrique IV y } \\
\text { el conde de Alba. Este se ha confederado con Juan } \\
\text { Pacheco, Pedro Girón y Alfonso Fonseca (Paz y } \\
\text { Melia, Ilustraciones, doc. 5, pp. 10-12). } \\
\text { - Marzo 1457. Nuevas cartas de confederación de } \\
\text { este grupo y de Lope de Barrientos con el rey. Este } \\
\text { círculo es el principal valedor del rey (Paz y Melia, } \\
\text { Ilustraciones, docs. 6-7, pp. 12-13). } \\
\text { - A partir de 1457 el conde se acerca a la conspi- } \\
\text { ración puesta en marcha por Alonso Carrillo. Hacia } \\
\text { 1459 se halla en situación incierta, o bien incluso } \\
\text { unido a la liga, según se sabe por quejas que en } \\
\text { agosto expresa Enrique IV al conde de Arcos (Pa- } \\
\text { lencia, Crónica, I, p. 242; Crónica castellana, pp. 67, } \\
\text { 69; ADA, c.62.4; Memorias Enrique IV, doc. 62, p. } \\
\text { 210; Crónica castellana, p. 104). }\end{array}$ & $\begin{array}{l}\text { - 1455. Nuevo testamento del } \\
\text { conde de Alba. Su primogénito } \\
\text { heredaría los mayorazgos de Alba, } \\
\text { Valdecorneja y las villas de Torre- } \\
\text { jón de Velasco, Salvatierra, Gra- } \\
\text { nadilla y Miranda del Castańar } \\
\text { (ADA, c.143.15). } \\
\text { - 16-11-1456. El conde de Alba } \\
\text { hace un trueque con Aldonza } \\
\text { Guzmán por el que cedía Jume- } \\
\text { la y Gálvez a cambio de recibir } \\
\text { Puente del Congosto y los bienes } \\
\text { que aquella tenía en esta loca- } \\
\text { lidad, en Peñafor, Armenteros, } \\
\text { Cespedosa, Gallegos de Solmi- } \\
\text { rón y Narrillos, lugares de Ávila } \\
\text { (ADA, c.157.23). }\end{array}$ \\
\hline $\begin{array}{l}\text { - 1460. Liga contra Juan Pacheco. De- } \\
\text { fienden a Alfonso, hermanastro de Enrique } \\
\text { IV, como heredero. Forman parte de la liga: } \\
\text { Alonso Carrillo; Fadrique Enríquez, almi- } \\
\text { rante de Castilla; Pedro Fernández de Ve- } \\
\text { lasco; Rodrigo Alonso de Pimentel; Diego } \\
\text { López de Estúniga; Enrique Enríquez, conde } \\
\text { de Alba de Liste; Pedro Manrique, conde de } \\
\text { Trevińo. Se une a la liga Juan II de Aragón, } \\
\text { que quiere recuperar el influjo que los infan- } \\
\text { tes de Aragón tuvieron décadas atrás. }\end{array}$ & $\begin{array}{l}\text { - 6-8-1460. El conde de Alba se halla unido a la } \\
\text { liga que, comandada por Carrillo, el nuevo mar- } \\
\text { qués de Santillana Diego Hurtado de Mendoza y } \\
\text { otros grandes nobles, se completa con un pacto } \\
\text { firmado con Juan II de Aragón y Navarra (Paz y } \\
\text { Melia, Ilustraciones, doc. 8, pp. 13-19; Palencia, } \\
\text { Crónica, I, pp. 323-324; Valera, Memorial, p. 21; } \\
\text { Crónica castellana, p. 106). }\end{array}$ & \\
\hline $\begin{array}{l}\text { - 1461. Enrique IV acepta las condiciones } \\
\text { de la liga nobiliaria. } \\
\text { - 1462. Creciente influjo de Beltrán de la } \\
\text { Cueva sobre el rey. Pacheco se pasa a la liga } \\
\text { nobiliaria, que, junto con Alonso Carrillo, } \\
\text { liderará desde entonces. El rey cuenta con } \\
\text { pocos apoyos, entre ellos los Mendoza. }\end{array}$ & $\begin{array}{l}\text { - Mayo-1461. El conde de Alba participa en los } \\
\text { pactos de pacificación de Enrique IV y la liga no- } \\
\text { biliaria (AHN, Nobleza, Frías, C.9, D.1; Memorias } \\
\text { Enrique IV, doc. 67, pp. 225-226; Crónica castella- } \\
\text { na, p. 112). } \\
\text { - 12-4-1462. Amistad entre el conde de Alba y } \\
\text { Juan II, rey de Aragón (Documentos escogidos, p. 5). }\end{array}$ & $\begin{array}{l}\text { - 15-12-1461. Enrique IV con- } \\
\text { cede el alguacilazgo mayor de To- } \\
\text { ledo a García Álvarez de Toledo } \\
\text { (AHN, Nobleza, Frías, C.847, } \\
\text { D.1). }\end{array}$ \\
\hline
\end{tabular}


JOSÉ MARÍA MONSALVO ANTÓN

- 1464. La liga nobiliaria contraria a Beltrán de la Cueva, que actúa decididamente desde la primavera, se hace con el poder. A finales de ese año conseguirán que Enrique IV reconozca como heredero al niño Alfonso.

Los hombres fuertes de esta liga son Alonso Carrillo, Juan Pacheco y su hermano Pedro Girón, Álvaro de Estúniga, Rodrigo Pimentel, Fadrique Enríquez y Pedro Manrique.

- 28-9-1464. Condiciones de la liga encabezada por el marqués de Villena, con gran respaldo de otros grandes. Exigían al monarca bel -que estaban bajo el poder del privado-, la proclamación de Alfonso como heredero, a costa de la hija de Enrique IV, Juana, declarada ilegítima.

- 30-11-1464. Nueva capitulación firmada entre Cabezón y Cigales por la que transitoriamente Enrique IV acepta como heredero a su hermanastro Alfonso -a quien se le entregaría el maestrazgo de Santiago-, se compromete a no casar a Isabel sin consentimiento de los estados del reino y se aviene a apartar de la corte a Beltrán de la Cueva.

- Diciembre-1464. Enrique IV pretende la monio entre la heredera Juana, su hija, y el heredero defendido por la liga, su hermanastro Alfonso. El plan de Enrique IV no fructificó. có.

\section{C.} que expulsara de la corte a Beltrán de la Cueva, la liberación de los infantes Alfonso e Isapacificación de las parcialidades con un matri-

- Primavera, 1464. El nuevo conde de Alba aparece citado con otros miembros de la nobleza (Carrillo, el almirante, el conde de Plasencia, el conde de Benavente, el conde de Alba de Liste, Juan Pacheco y su hermano Pedro Girón, el marqués de Santillana, el conde de Paredes, el conde de Ledesma don Beltrán de la Cueva, Pedro de Velasco, Lorenzo de Figueroa, el obispo de Calahorra Pedro Mendoza, entre otros) en un proyecto de pacto con Enrique IV y su mujer la reina dońa Juana para la pacificación del reino. La confederación e amistad, que no aparece firmada, si llegó a fraguar, tuvo corta vida (AGS, PTR, leg. 11, doc. 79; PTR, leg. 7, doc. 110).

- 6-6-1464. El nuevo conde de Alba, don García, firma con Enrique IV y la reina una carta de amistad. Asegura todos sus señoríos. (ADA, c.13.14; Documentos escogidos, pp. 5-6; Paz y Melia, Ilustraciones, doc. 13, pp. 71-72).

- 1464. Aparece firmando amistad con Juan de Navarra y los miembros de la liga para imponer condiciones a Enrique IV (AHN. Nobleza, Osuna, C.445, D.3; Memorias Enrique IV, doc. 95, pp. 321-326). - 7-8-1464. Confederación del conde de Alba y Juan Pacheco, que capitaneaba la liga proalfonsina (AHN, Nobleza, Frías, C.13, D.14).

- En septiembre de 1464 estaba actuando con la liga liderada por Pacheco. Intentos de prender al rey protagonizados por los condes de Alba y Plasencia (Memorias Enrique IV, doc. 97, pp. 327-334, doc. 98, pp. 334-335; Paz y Melia, Ilustraciones, docs. 10-12, pp. 58-71; Palencia, Crónica, I, pp. 419-420; Enríquez del Castillo, Crónica Enrique IV, pp. 133135; Crónica, ed. Sánchez Martín, pp. 216-218).

- 30-11-1464. El conde de Alba con otros grandes firma el acuerdo de Cigales de reconocimiento del heredero Alfonso. También ha firmado el seguro para la salida de Beltrán de la Cueva de la corte (Palencia, Crónica, I, pp. 419-420; AHN, Nobleza, Frías, C.15, D.3,4-5; Memorias Enrique IV, docs. 102, 103 , pp. 340-346, 355-366).

- 5-12-1464. El conde firma con otros en Cigales las peticiones para la pacificación del reino (AHN, Nobleza, Frías, C.9, D.3; CODOIN, t. XIV, pp. 369-395).

1465. Farsa de Ávila. Apoyo del conde de Alba a Enrique IV.

- La llamada Sentencia de Medina del - Primeros meses de 1465. El conde de Alba apaCampo, de finales de diciembre de 1464, rece ahora alineado con Enrique IV (ADA, c.61.7; dada a conocer en enero de 1465, reflejaba c.317.13; Palencia, Crónica, I, pp. 437-438). el peso de la liga nobiliaria en el gobierno del - Abril, 1465. Alarde en Alba de Tormes para servir reino. Controla el Consejo, aparta a Beltrán al rey (DCasaAlba-Ávila, doc. 52). de la Cueva de la corte, se reconoce al infante
- 1464. Muerte de Fernando Álvarez de Toledo. Hereda todos sus estados García Álvarez de Toledo. Desde mayo aparecerá en la documentación situado ya al frente de sus estados.

- Comienzos de 1465. Posibles promesas del rey al conde de Alba de la fortaleza de El Carpio (castillo enclavado en la Tierra de Salamanca) y otras posibles concesiones (Abadía, en Granadilla, al 


\section{JOSÉ MARÍA MONSALVO ANTÓN \\ RELACIONES ENTRE NOBLEZA Y MONARQUÍA EN EL SIGLO XV: FACCIONALISMO Y ACCIÓN POLÍTICA DE LOS ÁLVAREZ DE TOLEDO (CASA DE ALBA)}

\begin{tabular}{|c|c|c|}
\hline $\begin{array}{l}\text { Alfonso sucesor en el trono. Se apaciguan } \\
\text { momentáneamente las relaciones de Enrique } \\
\text { IV con algunos nobles. Carrillo, Pedro Man- } \\
\text { rique, Fadrique Enríquez y el conde de Alba } \\
\text { se reconcilian con el rey. } \\
\text { - Comienzos de 1465. El almirante Fa- } \\
\text { drique, el arzobispo Carrillo y el conde de } \\
\text { Treviño abandonan a Enrique IV y se pasan } \\
\text { al bando alfonsino con Pacheco. La liga or- } \\
\text { ganiza una rebelión militar. } \\
\text {-5-6-1465. Destronamiento simbólico de } \\
\text { Enrique IV. Tras la Farsa de Ávila, guerra } \\
\text { abierta contra Enrique IV y sus partidarios. } \\
\text { Apoyan la causa rebelde: el arzobispo Carri- } \\
\text { llo; don Fadrique, almirante; Juan Pacheco; } \\
\text { Pedro Girón, su hermano; Gómez de Solís, } \\
\text { maestre de Alcántara; Álvaro de Estúńiga; } \\
\text { Diego López de Estúniga, conde de Miran- } \\
\text { da; Rodrigo Alonso Pimentel; Pedro Porto- } \\
\text { carrero, conde de Medellín; Rodrigo Manri- } \\
\text { que, conde de Paredes. Y otros muchos. } \\
\text { Apoyan a Enrique IV: Diego Hurtado de } \\
\text { Mendoza, marqués de Santillana; Íńigo } \\
\text { López de Mendoza, su hermano, conde de } \\
\text { Tendilla; Pedro Fernández de Velasco, conde } \\
\text { de Haro; Álvaro Pérez Osorio; Beltrán de la } \\
\text { Cueva, duque de Alburquerque y conde de } \\
\text { Ledesma. }\end{array}$ & $\begin{array}{l}\text { - A principios de mayo Enrique IV acude a Alba } \\
\text { de Tormes y sella una sólida alianza con el conde } \\
\text { (Palencia, Crónica, I, p. 445; Enríquez del Castillo, } \\
\text { Crónica Enrique IV, p. 142; Crónica, ed. Sánchez } \\
\text { Martín, pp. 231-232; Itinerario de Enrique IV, ed. } \\
\text { Torres Fontes, p. 175). } \\
\text { - Poco antes de la Farsa de Ávila, Enrique IV y el } \\
\text { conde de Alba reafirman su alianza en Salamanca } \\
\text { (Itinerario Enrique IV, p. 177). } \\
\text { - Mayo, 1465. El conde de Alba era seguido por } \\
\text { una parcialidad en Salamanca, enfrentada a la del } \\
\text { conde de Plasencia Álvaro de Estúńiga (Crónica } \\
\text { castellana, p. 156; Galíndez, Crónica Enrique IV, p. } \\
\text { 232; Palencia, Crónica, I, p. 445). } \\
\text { - Tras la Farsa de Ávila, García Álvarez de Toledo, } \\
\text { que era ya suyo (según la crónica de Enríquez del } \\
\text { Castillo) pone a disposición de Enrique IV un } \\
\text { nutrido grupo de hombres armados: según esta } \\
\text { crónica, 300 hombres, 200 jinetes y 1.000 peones; } \\
\text { según Palencia, 800 hombres a caballo, agradecien- } \\
\text { do como oviese recebido gran suma de dineros del rey } \\
\text { Enrique. Otros cronistas dan otras cifras. (Enríquez } \\
\text { del Castillo, Crónica Enrique IV, pp. 144-146; Cró- } \\
\text { nica, ed. Sánchez Martín, pp. 238-239; Valera, Me- } \\
\text { morial, pp. 33-36; Pulgar, Crónica Reyes Católicos, } \\
\text { p. 230; Palencia, Crónica, I, pp. 474, 488; Crónica } \\
\text { castellana, pp. 164, 169). } \\
\text { - 15-7-1465. Confederación de amistad del conde } \\
\text { de Alba con Beltrán de la Cueva, Pedro González } \\
\text { de Mendoza y Gómez Suárez de Figueroa, partida- } \\
\text { rios de Enrique IV (RAH, SyC, K-37, fol. 30r-v). } \\
\text { - Verano de 1465. Actuaciones militares del con- } \\
\text { de de Alba en el bando enriquista (Enríquez del } \\
\text { Castillo, Crónica Enrique IV, p. 148; Crónica, ed. } \\
\text { Sánchez Martín, p. 244). } \\
\end{array}$ & $\begin{array}{l}\text { sur del Sistema Central) (Crónica } \\
\text { castellana, p. 153). } \\
\text { - 10-1-1465. El rey concede al } \\
\text { conde de Alba, queriendo ganar } \\
\text { su apoyo, el seńorío y castillo de } \\
\text { El Carpio (ADA, c.317.13; DCa- } \\
\text { saAlba-Salamanca, doc. 43). } \\
\text { - Febrero, 1465. Enrique IV } \\
\text { restituye al conde Villanueva de } \\
\text { Cañedo, fortaleza que había sido } \\
\text { secuestrada cuando la prisión del } \\
\text { padre del conde y aún no recupe- } \\
\text { rada (ADA, c.198.24). } \\
\text { - 20-11-1465. Enrique IV hace } \\
\text { merced al conde de Alba de las } \\
\text { tercias reales de Salvatierra de } \\
\text { Tormes (ADA, c.256.45). } \\
\text { - 15-12-1465. Noticia de que } \\
\text { Enrique IV concede al conde } \\
\text { 20.000 mrs salvados de rentas en } \\
\text { el obispado de Salamanca (ADA, } \\
\text { c.317.13; DCasaAlba-Salamanca, } \\
\text { doc. 45). } \\
\text { - 1465. Promesas verbales de } \\
\text { Enrique IV de entregar Ciudad } \\
\text { Rodrigo al conde de Alba (ADA, } \\
\text { c.156.30; DCasaAlba-Salamanca, } \\
\text { doc. 46). }\end{array}$ \\
\hline \multicolumn{3}{|c|}{ 1466-1468. Guerra entre los partidarios de Enrique IV y Alfonso de Ávila. Cambios de bando del conde de Alba. } \\
\hline $\begin{array}{l}\text { - 1465-1468. Guerra internobiliar entre } \\
\text { los partidarios de Enrique IV (linajes Cueva, } \\
\text { Mendoza, Osorio, inicialmente Alba) frente } \\
\text { a los partidarios de Alfonso de Ávila (Carri- } \\
\text { llo, Pacheco, Pimentel, Estúniga, Manrique, } \\
\text { Enríquez). Se producen situaciones confusas } \\
\text { y cambios de bando. }\end{array}$ & \begin{tabular}{|l|} 
- Marzo de 1466. Confederación entre Beltrán de \\
la Cueva, el marqués de Santillana Diego Hurtado \\
de Mendoza, su hermano el obispo Pedro Gonzá- \\
lez de Mendoza y el conde de Alba, partidarios de \\
la causa enriquista. (RAH, SyC, M-9, fols. 404v- \\
405r; AHN, Nobleza, Osuna, C.1860, D.16). \\
- ca. marzo de 1466. Confederación entre Beltrán \\
de la Cueva, el marqués de Santillana, su hermano \\
Pedro González de Mendoza y el conde de Alba \\
(AHN, Nobleza, Osuna, C.1860, D.15). \\
- 24-3-1466. La reina Juana firma esta amistad y \\
da seguro al conde (Documentos escogidos, p. 7). \\
- 1-7-1466. Enrique IV y la reina Juana prometen \\
entregar al conde la custodia de la princesa Juana \\
(ADA, c.1.12; DCasaAlba-Salamanca, doc. 47).
\end{tabular} & $\begin{array}{l}\text { - 8-1-1466. Enrique IV con- } \\
\text { cede a Mencía Carrillo, viuda de } \\
\text { Fernando Álvarez de Toledo y } \\
\text { madre del conde, } 50 \text { excusados } \\
\text { en el obispado de Salamanca, se- } \\
\text { gún documento de } 1470 \text { (ADA, } \\
\text { c.62.76). } \\
\text { - 16-6-1467. El pretendiente } \\
\text { Alfonso de Ávila concede al conde } \\
\text { el juzgado y alcaidía de las pagas } \\
\text { de los castillos del reino de Sevilla } \\
\text { fronteros con Granada (Morales } \\
\text { Muñiz, Dolores Carmen. Con- } \\
\text { tribución al registro del rey Alfonso } \\
\text { XII de Castilla. La documentación }\end{array}$ \\
\hline
\end{tabular}


JOSÉ MARÍA MONSALVO ANTÓN

\begin{tabular}{|c|c|c|}
\hline $\begin{array}{l}\text { - Tras la (segunda) batalla de Olmedo de } \\
\text { 19-8-1467, con victoria de Enrique IV, los } \\
\text { alfonsinos recuperan la iniciativa y toman } \\
\text { Segovia. }\end{array}$ & $\begin{array}{l}\text { - 17-10-1466. Alianza del conde de Alba con el } \\
\text { obispo de Ávila (Documentación histórica del Archi- } \\
\text { vo Municipal de Alba de Tormes (siglo XV), ed. J. Ma. } \\
\text { Monsalvo. Salamanca: Diputación de Salamanca, } \\
\text { 1988, doc. 184). } \\
\text { - } 1 \text { y 3-7-1467. Amistad con Juan Pacheco. Se } \\
\text { prometen apoyo recíproco fuese cual fuese el des- } \\
\text { enlace del conflicto (RAH, SyC, N-44, fols. 454r- } \\
\text { 455r; K-37, fols. 39v-40r). } \\
\text { - Verano de 1467. No acude a la batalla de Olme- } \\
\text { do. El conde se había pasado al bando alfonsino, } \\
\text { atraído por promesas de Carrillo y Pacheco de mer- } \\
\text { cedes y seńoríos. El rey intenta atraerlo con medio } \\
\text { cuento de mrs, entre otras cosas. Pese a la palabra } \\
\text { dada, no lo hizo, ya que, según Enríquez del Cas- } \\
\text { tillo, era caballero movible, e de poca firmeza, más } \\
\text { amigo del interese que no de la honra (...); todos los de } \\
\text { entranbos partidos mormurando descian que se avía } \\
\text { vendido en pública almoneda (...) que los mozos de } \\
\text { espuelas se atrevian a descir sin miedo, donde quiera } \\
\text { que lo vían, iquién da más por el conde de Alva, que } \\
\text { se vende a cada cantón? (Enríquez del Castillo, Cró- } \\
\text { nica Enrique IV, pp. 162, 166; Crónica, ed. Sánchez } \\
\text { Martín, pp. 272-273, 281-282; Palencia, Crónica, } \\
\text { II, pp. } 51-52 \text {, 77-78; Crónica castellana, pp. 205, } \\
\text { 216). } \\
\text { - Ya en el bando de los alfonsinos, el conde de Alba } \\
\text { participa en la toma de Segovia, en septiembre de } \\
\text { 1467, y da garantías a Isabel, que pasará a ser cus- } \\
\text { todiada por los alfonsinos (Enríquez del Castillo, } \\
\text { Crónica Enrique IV, p. 170; Crónica, ed. Sánchez } \\
\text { Martín, p. 290; Valera, Memorial, pp. } 41-43 \text {; Pa- } \\
\text { lencia, Crónica, II, pp. 92, 95, 99-100; Documentos } \\
\text { escogidos, pp. 8-9). } \\
\text { - En otońo de } 1467 \text { aparece como miembro des- } \\
\text { tacado entre los alfonsinos, ya hasta el final de la } \\
\text { guerra (Palencia, Crónica, II, p. 107). } \\
\text { - Otońo 1467. El conde firma, junto con Carrillo } \\
\text { y el maestre de Calatrava, la carta de seguro con que } \\
\text { el rey Alfonso acepta que Isabel visitara o residiera } \\
\text { en Arévalo, como pretendía (Documentos escogidos, } \\
\text { pp. 8-9; DCasaAlba-Ávila, doc. 56). }\end{array}$ & $\begin{array}{l}\text { de Avila. Madrid: Escuela Uni- } \\
\text { versitaria de Formación del Pro- } \\
\text { fesorado de E.G.B. Santa María, } \\
\text { 1991, doc. 127). } \\
\text { - Verano 1467. Pacheco y Ca- } \\
\text { rrillo entregan al conde de Alba, } \\
\text { como garantía de otros seńoríos } \\
\text { posibles, la encomienda de Mon- } \\
\text { talbán, de la Orden de Santiago, } \\
\text { cuyo maestre era Juan Pacheco, y } \\
\text { Puente del Arzobispo, de Alonso } \\
\text { Carrillo (Enríquez del Castillo, } \\
\text { Crónica Enrique IV, pp. 166- } \\
\text { 167). } \\
\text { - 4-9-1467. Fernando de Aya- } \\
\text { la, caballero del conde de Alba, } \\
\text { en su nombre, recibe Puente del } \\
\text { Arzobispo con sus rentas, como } \\
\text { garantía de la futura concesión de } \\
\text { Ciudad Rodrigo -en su defecto, } \\
\text { Toro o Madrigal- que Carrillo y } \\
\text { Pacheco han prometido al conde } \\
\text { si se pasaba a su bando, como así } \\
\text { hizo (ADA, c.62.28; DCasaAlba- } \\
\text { Salamanca, doc. 49). } \\
\text { - Noviembre } 1467 \text {. El rey Al- } \\
\text { fonso le confirma todas las merce- } \\
\text { des de los reyes anteriores porque } \\
\text { venistes a a me servir e dexades de } \\
\text { seguir al dicho don Enrrique, mi } \\
\text { antecesor. Además hacía efectiva la } \\
\text { alcaidía de las pagas de los castillos } \\
\text { fronteros con Granada, la alcaldía } \\
\text { mayor de las sacas del obispado de } \\
\text { Cuenca y el marco de plata por las } \\
\text { escrituras de privilegio del reino } \\
\text { (DCasaAlba-Salamanca, doc. 50; } \\
\text { MoralEs MuñIz, Contribución } \\
\text { al registro del rey Alfonso XII, docs. } \\
\text { 149, 150, 151). }\end{array}$ \\
\hline \multicolumn{3}{|c|}{ 1468-1474. Últimos ańos conflictivos de Enrique IV. García Álvarez de Toledo, convertido en duque de Alba. } \\
\hline $\begin{array}{l}\text { - 5-7-1468. Muerte del pretendiente Al- } \\
\text { fonso. Los alfonsinos inician nuevas manio- } \\
\text { bras y reajustes sucesorios y políticos. } \\
\text { - } 18-9-1468 \text {. Pacto de los Toros de Gui- } \\
\text { sando, que pone fin al conflicto y prepara la } \\
\text { sucesión de Isabel como heredera al trono. }\end{array}$ & $\begin{array}{l}\text { - Agosto de 1468. Presente en la pacificación } \\
\text { momentánea tras la muerte del príncipe Alfonso. } \\
\text { Participa en el bando isabelino en las negociaciones } \\
\text { que condujeron a los Toros de Guisando (Palencia, } \\
\text { Crónica, II, p. 176; Crónica castellana, p. 248). }\end{array}$ & $\begin{array}{l}\text { - 14-4-1468. El rey Alfonso } \\
\text { hace merced al conde de Alba } \\
\text { de } 100.000 \text { mrs situados en la } \\
\text { renta de los ganados del puerto } \\
\text { de Abadía, aldea de Granadilla } \\
\text { (Morales MuñIZ, Contribución } \\
\text { al registro del rey Alfonso XII, doc. } \\
\text { 180). }\end{array}$ \\
\hline
\end{tabular}


JOSÉ MARÍA MONSALVO ANTÓN

RELACIONES ENTRE NOBLEZA Y MONARQUÍA EN EL SIGLO XV: FACCIONALISMO Y ACCIÓN POLÍticA DE LOS ÁlVAREZ DE TOLEDO (CASA DE ALBA)

\begin{tabular}{|c|c|c|}
\hline $\begin{array}{l}\text { - 1469-1474. Juan Pacheco consigue neu- } \\
\text { tralizar el Pacto de los Toros de Guisando, } \\
\text { tras el matrimonio de Isabel. Pacheco, } \\
\text { marqués de Villena y maestre de Santiago, } \\
\text { sella una alianza con Enrique IV, Alfonso de } \\
\text { Fonseca, arzobispo de Sevilla, Álvaro de Es- } \\
\text { túńiga y Rodrigo Alonso Pimentel a finales } \\
\text { de } 1468 \text {. Se le unen otros nobles, como los } \\
\text { Suárez de Figueroa y los Ponce de León. } \\
\text { Otro grupo nobiliario se vincula también a } \\
\text { ellos y a la causa enriquista: Diego Hurta- } \\
\text { do de Mendoza y su linaje, el linaje Velasco, } \\
\text { Cueva y algunos otros. Desde mayo de 1469, } \\
\text { aunque con rivalidades latentes hacia el otro } \\
\text { sector, este grupo se alía con el de Juan Pa- } \\
\text { checo y la causa de la heredera Juana. En } \\
\text { alianzas exteriores, se inclinan por la alianza } \\
\text { con Alfonso V, rey de Portugal, país de pro- } \\
\text { cedencia de la reina Juana. } \\
\text { Desde } 1470 \text { Enrique IV retoma la causa de } \\
\text { su hija Juana y revoca el juramento a su her- } \\
\text { manastra Isabel, desandando lo pactado dos } \\
\text { ańos antes. } \\
\text { Frente al sector enriquista y portugués, otra } \\
\text { parte de la nobleza apoyaba a Isabel: Carrillo, } \\
\text { los Manrique, los Enríquez y los Guzmán Se } \\
\text { inclinan por Aragón y por su rey Juan II. En } \\
\text { octubre de } 1469 \text {, por su matrimonio, Isabel } \\
\text { ha enlazado con el heredero aragonés. Juan } \\
\text { II de Aragón, el antes infante rebelde, apoya } \\
\text { a este sector isabelino, liderado por Alonso } \\
\text { Carrillo, arzobispo de Toledo. }\end{array}$ & 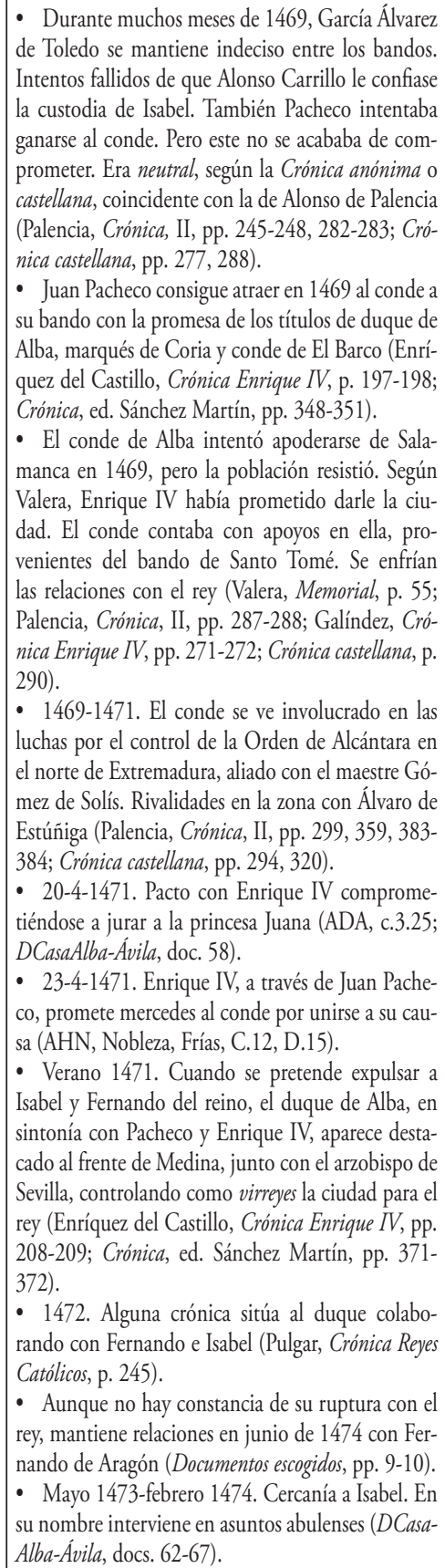 & 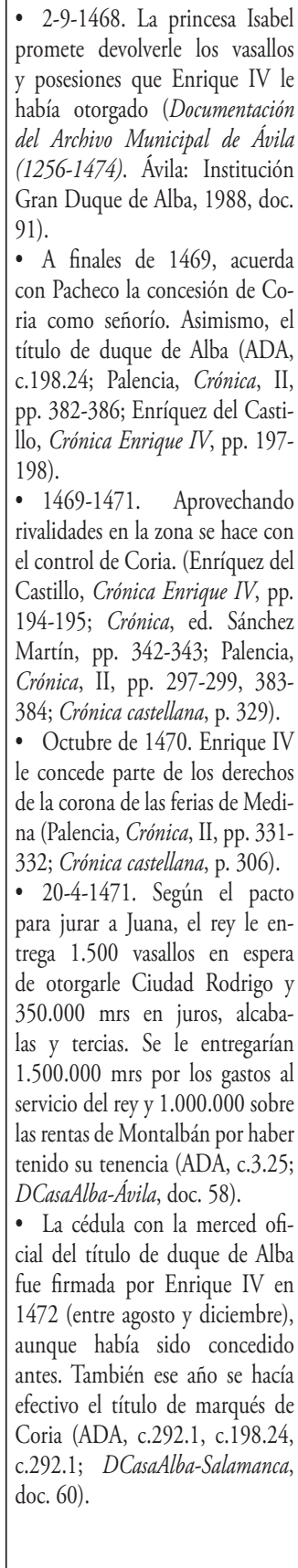 \\
\hline
\end{tabular}


JOSÉ MARÍA MONSALVO ANTÓN

\begin{tabular}{|c|c|c|}
\hline & $\begin{array}{l}\text { - A lo largo de } 1474 \text { encuentros y relaciones con } \\
\text { el partido de Fernando e Isabel, aunque Pacheco } \\
\text { trataba de atraerlo a su causa, sin éxito (Palencia, } \\
\text { Crónica, III, pp. 215, 219, 276; Crónica castellana, } \\
\text { p. 442). }\end{array}$ & \\
\hline \multicolumn{3}{|c|}{ 1475-1479. Reinado de Isabel I. Consolidación de la posición del duque de Alba. } \\
\hline $\begin{array}{l}\text { - Finales } 1474 \text {-comienzos } 1475 \text {. Tras la } \\
\text { muerte de Enrique IV a mediados de di- } \\
\text { ciembre, la mayoría de los linajes nobiliarios } \\
\text { castellanos proclaman a Isabel: Mendoza, } \\
\text { Velasco, Enríquez, Manrique, Quiñones, } \\
\text { Pimentel, Arellano, Guzmán, Álvarez de To- } \\
\text { ledo. } \\
\text { Por el contrario, no reconocieron a Isabel y } \\
\text { defendieron la causa de la princesa Juana: } \\
\text { Carrillo, Estúniga y Diego López Pache- } \\
\text { co. Son minoritarios entre la nobleza, pero } \\
\text { cuentan con el respaldo de Portugal. } \\
\text { - Desde la primavera de } 1475 \text { ambos ban- } \\
\text { dos se enfrentan mediatizados por el conflic- } \\
\text { to castellano-portugués. Las tropas de Alfon- } \\
\text { so V de Portugal entran en Castilla en apoyo } \\
\text { de la cuasa de Juana. } \\
\text { - El conflicto armado se prolonga hasta } \\
1479 \text {. }\end{array}$ & 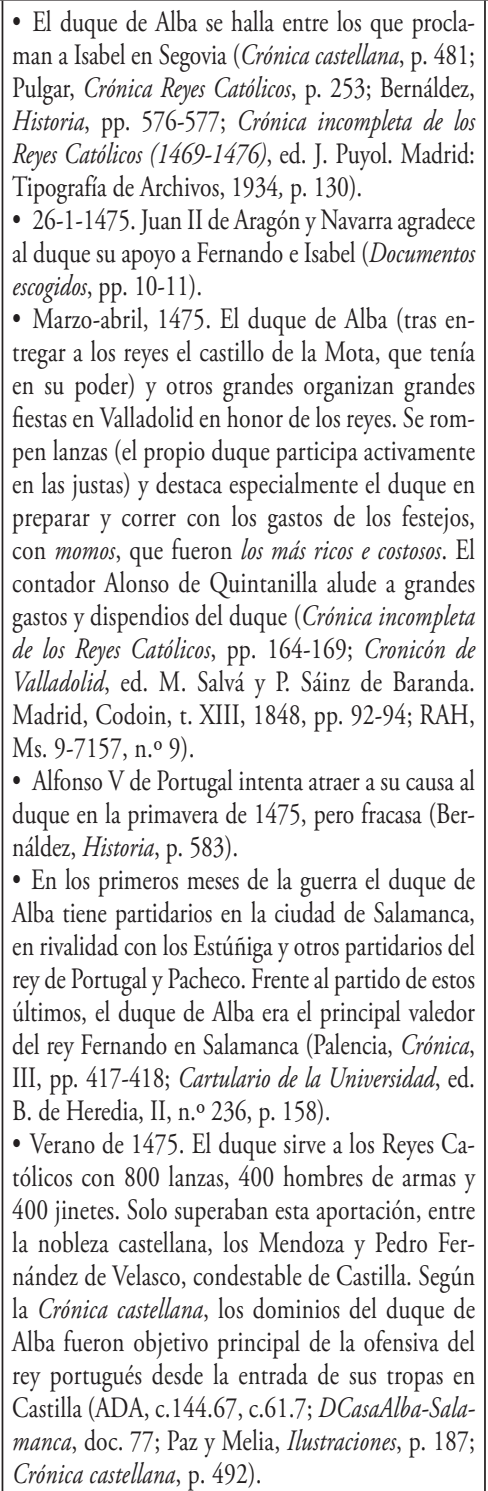 & $\begin{array}{l}\text { - 1476. Concesión del señorío } \\
\text { sobre San Felices de los Gallegos } \\
\text { (Paz y Melia, Ilustraciones, p. 384; } \\
\text { Palencia, Crónica, IV, pp. 203- } \\
\text { 204). } \\
\text { - Abril, 1476. Concesión de } \\
\text { los bienes confiscados a Antón } \\
\text { Núnez de Ciudad Rodrigo, an- } \\
\text { tiguo contador de Enrique IV y } \\
\text { destacado aliado de los portu- } \\
\text { gueses. También hacen merced } \\
\text { de los bienes de otro caballero } \\
\text { mirobrigense, Alvar Pérez Oso- } \\
\text { rio, alineado también con los } \\
\text { portugueses. Además, recibió } \\
\text { 150.000 mrs de las alcabalas de } \\
\text { Coria (ADA, c.1.18, c.198.24; } \\
\text { DCasaAlba-Salamanca, docs. } \\
\text { 78, 79). }\end{array}$ \\
\hline
\end{tabular}


JOSÉ MARÍA MONSALVO ANTÓN

RELACIONES ENTRE NOBLEZA Y MONARQUÍA EN EL SIGLO XV: FACCIONALISMO Y ACCIÓN POLÍTICA DE LOS ÁLVAREZ DE TOLEDO (CASA DE ALBA)

\begin{tabular}{|c|c|c|}
\hline & $\begin{array}{l}\text { - Durante la guerra, interviene de forma destaca- } \\
\text { da en muchas acciones. Participa activamente en la } \\
\text { batalla de Toro de marzo de } 1476 \text { (el duque de Alua, } \\
\text { con mill y dosçientas lanças, las más atauiadas que en } \\
\text { España fueron vistas, según la Crónica incompleta) } \\
\text { y en otras acciones militares (Archivo Municipal } \\
\text { de Ciudad Rodrigo. Leg. } 285 \text { (Leg. 2, n. }{ }^{\circ} 29 \mathrm{G} \text { ); } \\
\text { Palencia, Crónica, IV, pp. 92, 114, 117, 141, 160- } \\
\text { 161, 169, 315; Pulgar, Crónica Reyes Católicos, pp. } \\
\text { 293-297; Crónica incompleta de los Reyes Católicos, } \\
\text { pp. 208-212, 220). }\end{array}$ & $\begin{array}{l}\text { - Octubre 1477. Consigue pro- } \\
\text { mover a su hijo don Gutierre a } \\
\text { maestrescuela de Salamanca (Car- } \\
\text { tulario Universidad, II, n. }{ }^{\text {.s }} \text { 158, } \\
\text { 159, pp. 75, 76; ADA, c.62.63). }\end{array}$ \\
\hline $\begin{array}{l}\text { - Septiembre 1479. Paz de Alcaçovas con } \\
\text { Portugal y fin de los enfrentamientos abier- } \\
\text { tos internobiliarios. }\end{array}$ & $\begin{array}{l}\text { - Al terminar la guerra el duque de Alba se halla } \\
\text { entre los más importantes linajes de Castilla. }\end{array}$ & $\begin{array}{l}\text { - 30-1-1479. Licencia real al } \\
\text { duque para instituir mayoraz- } \\
\text { gos. Licencia de nuevo en } 1487 . \\
\text { En 22-5-1488 en el testamento } \\
\text { se mencionan los mayorazgos, } \\
\text { destacando los del primogénito, } \\
\text { Fadrique, que tendría el de Alba } \\
\text {-que incluía Coria y Granadilla y } \\
\text { otros concejos- y el de Valdecor- } \\
\text { neja (RAH, SyC, M-5, fols. 63v- } \\
\text { 70r; T-38, fols. 339r-342r; S- 41, } \\
\text { fols. 155r-158r). }\end{array}$ \\
\hline
\end{tabular}

\section{REFERENCIAS BIBLIOGRÁFICAS}

Bandos y querellas dinásticas en España al final de la Edad Media. Actas del Coloquio celebrado en la Biblioteca Española de París los días 15 y 16 de mayo de 1987. París: Biblioteca Española de París, 1991.

Beceiro Pita, Isabel. «Doléances et ligues de la noblesse dans la Castille de la fin du Moyen Âge (1420-1464)». En Rucquoi, Adeline (dir.). Genèse médiévale de l'Espagne Moderne. Du refus à la revolte: les résistances. Nice: Université de Nice, 1991, pp. 107-126.

Beceiro Pita, Isabel. «Parentesco y alianzas políticas en Castilla (siglo xv)». En Foronda, François y Carrasco Manchado, Ana Isabel (dirs.). Du contrat d'alliance au contrat politique. Cultures et sociétés politiques dans la Péninsule Ibérique de la fin du Moyen Âge. Toulouse: Université de Toulouse II-Le Mirail, 2007, pp. 9-28.

Bernáldez, Andrés. Historia de los Reyes Católicos. Crónicas de los Reyes de Castilla, ed. C. Rosell. Madrid: Rivadeneyra, 1878.

Calderón Ortega, José Manuel. «Aspectos políticos del proceso de formación de un estado señorial: el ducado de Alba y el señorío de Valdecorneja (1350-1488)». Cuadernos Abulenses, 1995, vol. 23, pp. 11-116.

Calderón Ortega, José Manuel. «El gobierno de la Casa de Alba (siglos XIV-Xvi)». En Ser QuiJANO, Gregorio del (coord.). Congreso V Centenario del nacimiento del III Duque de Alba Fernando Álvarez de Toledo. Actas. Âvila: Institución Gran Duque de Alba, 2008, pp.119-153.

Calderón Ortega, José Manuel. «Los riesgos de la política en el siglo xv: la prisión del conde de Alba (1448-1454)». Historia. Instituciones. Documentos, 1994, vol. 21, pp. 41-62.

Calderón Ortega, José Manuel. Álvaro de Luna (1419-1453). Colección diplomática. Madrid: Dykinson, 1999. 
JOSÉ MARÍA MONSALVO ANTÓN

182

RELACIONES ENTRE NOBLEZA Y MONARQUÍA EN EL SIGLO XV: FACCIONALISMO Y ACCIÓN POLÍTICA DE LOS ÁLVAREZ DE TOLEDO (CASA DE ALBA)

Calderón Ortega, José Manuel. El ducado de Alba. La evolución histórica, el gobierno y la hacienda de un estado señorial (siglos XIV-XVI). Madrid: Dykinson, 2005.

Calderón Ortega, José Manuel. El ducado de Alba. La evolución histórica, el gobierno y la hacienda de un estado señorial (siglos XIV-XVI). Madrid: Dykinson, 2005.

Carceller Cerviño, M. ${ }^{a}$ del Pilar. «Los bandos nobiliarios y la carrera política: ascenso y privanza de Beltrán de la Cueva». Anuario de Estudios Medievales, 2006, vol. 36, n. o 2, pp. 783-801.

Carrasco Manchado, Ana Isabel. "Entre el rey y el reino calladamente está fecho un contrato. Fundamentos contractuales de la monarquía Trastámara en Castilla en el siglo XV». En FoRONDA, François (dir.). Avant le contrat social. Le contrat politique dans l'Occident médiéval (XIII-XV siècle). Paris: Publications de la Sorbonne, 2011, pp. 613-652.

Carrasco Manchado, Ana Isabel. «Léxico político en el Seguro de Tordesillas: conflicto, pactos y autoridad real». En Foronda, François y Carrasco Manchado, Ana Isabel (dirs.). Du contrat d'alliance au contrat politique. Cultures et sociétés politiques dans la Péninsule Ibérique de la fin du Moyen Âge. Toulouse: Université de Toulouse II-Le Mirail, 2007, pp. 85-137.

Carrasco Manchado, Ana Isabel. Isabel I de Castilla y la sombra de la ilegitimidad. Propaganda y representación en el conflicto sucesorio (1474-1482). Madrid: Sílex, 2006.

Carrillo de Huete, Pedro. Crónica del Halconero de Juan II, ed. J. de Mata Carriazo. Madrid: Espasa-Calpe, 1946.

Cortes de los antiguos reinos de León y de Castilla. Madrid: Real Academia de la Historia, 1863.

Crónica anónima de Enrique IV de Castilla, 1454-1474 (Crónica castellana). Tomo II, Crónica, ed. M. a P. Sánchez-Parra. Madrid: Ediciones de La Torre, 1991.

Crónica de don Álvaro de Luna (atribuida a Gonzalo Chacón), ed. J. Mata Carriazo. Madrid: Espasa-Calpe, 1940.

Crónica de don Juan II de Castilla por Alvar García de Santa María (1420-1434), en Colección de documentos inéditos para la Historia de España. Madrid: s. n., 1891, t. XCIX-C.

Crónica de Juan II. Crónicas de los Reyes de Castilla, ed. C. Rosell. Madrid: Rivadeneyra, 1877.

Crónica incompleta de los Reyes Católicos (1469-1476), ed. J. Puyol. Madrid: Tipografía de Archivos, 1934.

Cronicón de Valladolid, ed. M. Salvá y P. Sáinz de Baranda. Madrid: s. n., Codoin, t. XIII, 1848.

Documentación histórica del Archivo Municipal de Alba de Tormes (siglo XV), ed. J. M. ${ }^{a}$ Monsalvo Antón. Salamanca: Diputación de Salamanca, 1988.

Documentación medieval abulense en el Archivo de la Casa de Alba, ed. J. M. Calderón Ortega. Ávila: Institución Gran Duque de Alba, 2000.

Documentos escogidos del Archivo de la Casa de Alba, ed. duquesa de Berwick y de Alba. Madrid: s. n., 1891.

Enríquez del Castillo, Diego. Crónica de don Enrique el cuarto. Crónicas de los Reyes de Castilla, ed. C. Rosell. Madrid: Rivadeneyra, 1878.

Foronda, François. «La monarchie élective dans la Castille du xve siècle. Retour sur la Farce d'Avila (5 juin 1465)». En Peneau, Corinne (dir.). Elections et pouvoirs politiques du vII au XVII siècle. Bordeaux-Pompignac: Editions Bière, 2008, pp. 351-381.

Foronda, François. «La privanza, entre monarquía y nobleza». En Nieto Soria, José Manuel (dir.). La monarquía como conflicto en la corona castellano-leonesa (c. 1230-1504). Madrid: Sílex, 2006, pp. 73-132.

Foronda, François. "Vers un gouvernement de jure dans la Castille du Xv siècle: les contrats de privanza d'Henri IV de Trastamare». En Foronda, François y Carrasco Manchado, Ana Isabel (dirs.). Du contrat d'alliance au contrat politique. Cultures et sociétés politiques dans la Péninsule Ibérique de la fin du Moyen Âge. Toulouse: Université de Toulouse II-Le Mirail, 2007, pp. 185-244. 
JOSÉ MARÍA MONSALVO ANTÓN

RELACIONES ENTRE NOBLEZA Y MONARQUÍA EN EL SIGLO XV: FACCIONALISMO Y ACCIÓN POLÍTICA DE LOS ÁLVAREZ DE TOLEDO (CASA DE ALBA)

Foronda, François. El espanto y el miedo. Golpismo, emociones políticas y constitucionalismo en la Edad Media. Madrid: Dykinson, 2013.

Foronda, François y Carrasco Manchado, Ana Isabel (dirs.). El contrato político en la Corona de Castilla. Cultura y sociedad politicas entre los siglos X al XVI. Madrid: Dykinson, 2008.

Franco Silva, Alfonso. El arzobispo de Toledo. Alonso Carrillo: un prelado belicoso del siglo XV, apasionado por la riqueza y el poder. Cádiz: Universidad de Cádiz, 2014.

Franco Silva, Alfonso. Juan Pacheco, privado de Enrique IV de Castilla. La pasión por la riqueza y el poder. Granada: Universidad de Granada, 2011.

Franco Silva, Alfonso. Los discursos politicos de la nobleza castellana en el siglo XV. Cádiz: Universidad de Cádiz, 2012.

Gerbet, Marie-Claude. La noblesse dans le royaume de Castille. Étude sur ses structures sociales en Estrémadure (1454-1516). Paris: Publications de la Sorbonne, 1979.

Gómez Redondo, Fernando. «Elocución y diplomacia: rivalidades culturales en Tordesillas». En Foronda, François y Carrasco Manchado, Ana Isabel (dirs.). Du contrat d'alliance au contrat politique. Cultures et sociétés politiques dans la Péninsule Ibérique de la fin du Moyen Âge. Toulouse: Université de Toulouse II-Le Mirail, 2007, pp. 49-64.

Jara Fuente, José Antonio. "Çercada de muchos contrarios. Didáctica de las relaciones políticas ciudad-nobleza en la Cuenca del siglo Xv». Edad Media. Revista de Historia, 2013, vol. 14, pp. 105-127.

Luis López, Carmelo. «El señorío de Valdecorneja». En Ser Quijano, Gregorio del (coord.). Historia de Ávila. Tomo III. La Edad Media (Siglos XIV y XV). Ávila: Institución Gran Duque de Alba, 2006, pp. 279-370.

Luis López, Carmelo. La Comunidad de villa y tierra de Piedrahita en el tránsito de la Edad Media a la Moderna. Ávila: Institución Gran Duque de Alba, 1987.

Marino, Nancy F. El «Seguro de Tordesillas» del conde de Haro don Pedro Fernández de Velasco. Valladolid: Universidad de Valladolid, 1992.

Memorias de don Enrique IV de Castilla. II. Colección diplomática del mismo rey. Madrid: Establecimiento Tipográfico de Fortanet, 1913.

Monsalvo Antón, José María. «Arraigo territorial de las grandes casas señoriales (infantes de Aragón, Alba, Estúníiga y Alburquerque) en la cuenca suroccidental del Duero en el contexto de la pugna "nobleza-monarquía"». Anales de la Universidad de Alicante. Historia Medieval, 2015-2016, vol. 19, pp. 111-164.

Monsalvo Antón, José María. «El lenguaje del poder en la Castilla del siglo xv: léxico político y alianzas nobiliarias de los Álvarez de Toledo (Casa de Alba)». En Carrasco Manchado, Ana Isabel. El historiador frente a las palabras. Lenguaje, poder y politica en la sociedad medieval. Nuevas herramientas y propuestas. Lugo: Axac (en prensa).

Monsalvo Antón, José María. «Esferas de poder nobiliario y relaciones con el poder regio en la Salamanca medieval: de la caballería concejil al duque de Alba». En Costa, Adelaide (coord.). Conflicto politico: lucha y cooperación. Ciudad y nobleza en Portugal y Castilla en la Baja Edad Media (coloquio Lisboa, dic. 2015). Lisboa (en prensa).

Monsalvo Antón, José María. El sistema político concejil. El ejemplo del señorío medieval de Alba de Tormes y su concejo de villa y tierra. Salamanca: Ediciones Universidad de Salamanca, 1988.

Morales Muñiz, Dolores Carmen. "Las confederaciones nobiliarias en Castilla durante la guerra civil de 1465». Anuario de Estudios Medievales, 1988, vol. 18, pp. 455-467.

Morales Muñiz, Dolores Carmen. Contribución al registro del rey Alfonso XII de Castilla. La documentación de Ávila. Madrid: Escuela Universitaria de Formación del Profesorado de E.G.B. Santa María, 1991. 
JOSÉ MARÍA MONSALVO ANTÓN

RELACIONES ENTRE NOBLEZA Y MONARQUÍA EN EL SIGLO XV: FACCIONALISMO Y ACCIÓN POLÍTICA DE LOS ÁLVAREZ DE TOLEDO (CASA DE ALBA)

Nieto Soria, José Manuel. «El consenso como representación en la monarquía de la Castilla trastámara: contextos y prácticas». Edad Media. Revista de Historia, 2010, vol. 11, pp. 37-62.

Nieto Soria, José Manuel. «La monarquía como conflicto de legitimidades». En Nieto SoRIA, José Manuel (dir.). La monarquía como conflicto en la corona castellano-leonesa (c. 12301504). Madrid: Sílex, 2006, pp. 13-72.

Nieto Soria, José Manuel. «La Realeza». En Nieto Soria, José Manuel (dir.). Orígenes de la Monarquía Hispánica: propaganda y legitimación (ca. 1400-1520). Madrid: Dykinson, 1999, pp. 25-62.

Nieto Soria, José Manuel. «Pacto y consenso en la cultura política medieval: algunas perspectivas de análisis». En Nieto Soria, José Manuel y Villarroel González, Óscar (coords.). Pacto y consenso en la cultura política peninsular. Siglos XI al XV. Madrid: Sílex, 2013, pp. 17-40.

Nieto Soria, José Manuel. Un crimen en la Corte. Caida y ascenso de Gutierre Álvarez de Toledo, señor de Alba (1376-1446). Madrid: Sílex, 2006.

Ortega Cervigón, José Ignacio. «Lazos clientelares y bandos nobiliarios conquenses durante el siglo XV». Espacio, Tiempo y Forma. Serie III, Historia Medieval, 2007, vol. 19, pp. 211-231.

Palencia, Alfonso de. Crónica de Enrique IV, ed. A. Paz y Melia. Madrid: Tipografía de la Revista de Archivos, 1904-1908.

Pastor Bodmer, Isabel. Grandeza y tragedia de un valido: la muerte de don Álvaro de Luna. II. Documentos. Madrid: Caja de Madrid, 1992.

Paz y Melia, Antonio. El cronista Alonso de Palencia. Su vida y obras; sus Décadas y las crónicas contemporáneas; ilustraciones de las Décadas y notas varias. Madrid: The Hispanic Society of America, 1914.

Pulgar, Hernando del. Crónica de los Reyes Católicos. Crónicas de los Reyes de Castilla, ed. C. Rosell. Madrid: Rivadeneyra, 1878.

Quintanilla Raso, María Concepción. «Conflictos entre grandes. De las luchas internobiliarias a los debates interseñoriales». En Nieto Soria, José Manuel (dir.). El conflicto en escenas. La pugna política como representación en la Castilla bajomedieval. Madrid: Sílex, 2010, pp. 59-104.

Quintanilla Raso, María Concepción. «Facciones, clientelas y partidos en España en el tránsito de la Edad Media a la Modernidad». En Alvarado, Javier. (coord.). Poder, economía, clientelismo. Madrid: Marcial Pons, 1997, pp. 15-50.

Quintanilla Raso, María Concepción. «Integración nobiliaria, violencia y faccionalidad en tiempos de Juan II». En El marqués de Santillana (1398-1458). Los albores de la España Moderna. II. El hombre de estado. Santander: Nerea, 2001, pp. 85-126.

Quintanilla Raso, María Concepción. "Les confédérations de nobles, et les bandos dans le royaume de Castille au bas Moyen Age. L'exemple de Cordoue». Journal of Medieval History, 1990, vol. 16, n. ${ }^{\circ}$ 2, pp. 165-179.

Quintanilla Raso, María Concepción. «Para nos guardar e ayudar el uno al otro: pactos de ayuda mutua entre los grandes en el ámbito territorial (el noroeste castellanoleonés, segunda mitad del siglo Xv)». Edad Media. Revista de Historia, 2010, vol. 11, pp. 91-121.

Quintanilla Raso, María Concepción. «Relaciones contractuales y propaganda de estatus: "unidad e amistança entre los Grandes del Reyno"». En Foronda, François y Carrasco Manchado, Ana Isabel (dirs.). Du contrat d'alliance au contrat politique. Cultures et sociétés politiques dans la Péninsule Ibérique de la fin du Moyen Âge. Toulouse: Université de Toulouse II-Le Mirail, 2007, pp. 29-47.

Quintanilla Raso, María Concepción. «Consenso, pacto, amistad y seguridad. Escrituras y tácticas nobiliarias en la Castilla del siglo XV». En Nieto Soria, José Manuel y Villarroel González, Óscar (coords.). Pacto y consenso en la cultura política peninsular. Siglos XI al XV. Madrid: Sílex, 2013, pp. 65-91. 
JOSÉ MARÍA MONSALVO ANTÓN

RELACIONES ENTRE NOBLEZA Y MONARQUÍA EN EL SIGLO XV: FACCIONALISMO Y ACCIÓN POLÍTICA DE LOS ÁLVAREZ DE TOLEDO (CASA DE ALBA)

Quintanilla Raso, María Concepción. «El engrandecimiento nobiliario en la Corona de Castilla. Las claves del proceso a finales de la Edad Media». En Quintanilla Raso, María Concepción (ed.). Títulos, grandes del reino y grandeza en la sociedad politica: sus fundamentos en la Castilla medieval. Madrid: Sílex, 2006, pp. 17-100.

Quintanilla Raso, María Concepción. «Política ciudadana y jerarquización del poder. Bandos y parcialidades en Cuenca». En la España Medieval, 1997, vol. 20, pp. 219-250.

Rábade Obradó, María del Pilar. «Confederaciones, seguros y pleitos homenajes: el contexto documental del Seguro de Tordesillas». En Foronda, François y Carrasco Manchado, Ana Isabel (dirs.). Du contrat d'alliance au contrat politique. Cultures et sociétés politiques dans la Péninsule Ibérique de la fin du Moyen Âge. Toulouse: Université de Toulouse II-Le Mirail, 2007, pp. 65-84.

Refundición de la Crónica del Halconero, atribuida a Lope de Barrientos, ed. J. de Mata Carriazo. Madrid: Espasa-Calpe, 1946.

Salamanca en la documentación medieval de la Casa de Alba, ed. Á. Vaca y J. A. Bonilla. Salamanca: Caja de Ahorros y Monte de Piedad de Salamanca, 1989.

SÁnchez Benito, José María. «Nobleza territorial y política ciudadana en el siglo xv (Los concejos del área del Tajo)». Espacio, Tiempo y Forma. Serie III, Historia Medieval, 2014, vol. 27, pp. 463-502.

Sánchez Martín, Aureliano. Crónica de Enrique IV de Diego Enríquez del Castillo, Valladolid: Universidad de Valladolid, 1994.

SÁnchez Prieto, Ana Belén. «Un tipo documental fundamentalmente nobiliario: la confederación. Aspectos jurídico-diplomáticos (siglos Xv-XvI)». Cuadernos de Estudios Medievales y Ciencias y Técnicas Historiográficas, 1995, vol. 20, pp. 47-63.

Santos Canalejo, Elisa Carolina de. La historia medieval de Plasencia y su entorno geohistórico: la sierra de Béjar y la sierra de Gredos. Cáceres: Institución Cultural El Brocense, 1986.

SuÁrez Fernández, Luis. «Un libro de asientos de Juan II». Hispania, 1957, vol. 68, pp. 322-368.

SuÁrez Fernández, Luis. Nobleza y monarquía. Puntos de vista sobre la historia politica castellana en el siglo XV. Valladolid: Universidad de Valladolid, 1975, 2. ${ }^{\mathrm{a}}$ ed.

Torres Fontes, Juan. Estudio sobre la «Crónica de Enrique IV» del Dr. Galíndez de Carvajal. Murcia: Suc. de Nogués, 1946.

Val Valdivieso, María Isabel del. «La farsa de Ávila en las crónicas de la época». En Ser QuijaNO, Gregorio del y Martín Viso, Ińaki (eds.). Espacios de poder y formas sociales en la Edad Media. Estudios dedicados a Ángel Barrios. Salamanca: 2007, pp. 355-367.

Val Valdivieso, María Isabel del. «Los bandos nobiliarios durante el reinado de Enrique IV». Hispania, 1975, vol. XXXV, n. ${ }^{\circ} 130$, pp. 249-293.

Valera, Diego de. Memorial de diversas hazañas. Crónicas de los reyes de Castilla, ed. C. Rosell. Madrid: Rivadeneyra, 1878.

Vargas-Zúniga y Montero de Espinosa, Antonio de y Cuartero y Huerta, Baltasar (eds.). Índice de la Colección de don Luis de Salazar y Castro. Tomo XXV, Documentos de Estado y Gobierno de España y confederaciones entre personajes (K-12 al K-37). Madrid: Real Academia de la Historia, 1960.

Villarroel González, Óscar. «Negociación y representación del consenso: los conflictos de época de Juan II de Castilla». En Nieto Soria, José Manuel y Villarroel González, Óscar (coords.). Pacto y consenso en la cultura política peninsular. Siglos XI al XV. Madrid: Sílex, 2013, pp. 237-259.

Villarroel González, Óscar. Juana la Beltraneja. La construcción de una ilegitimidad. Madrid: Sílex, 2014. 
